\title{
Harnessing NK Cell Checkpoint-Modulating Immunotherapies
}

\author{
Sachin Kumar Singh Chauhan ${ }^{1, *}$, Ulrike Koehl ${ }^{1,2,3}$ and Stephan Kloess ${ }^{1}$ \\ 1 Institute of cellular therapeutics, Hannover Medical School, 30625 Hannover, Germany; \\ Koehl.Ulrike@mh-hannover.de (U.K.); Kloess.Stephan@mh-hannover.de (S.K.) \\ 2 Fraunhofer Institute for Cell Therapy and Immunology, 04103 Leipzig, Germany \\ 3 Institute of Clinical Immunology, University of Leipzig, 04103 Leipzig, Germany \\ * Correspondence: chauhan.sachin@mh-hannover.de; Tel.: +49-(0)-511-532-8176
}

Received: 31 May 2020; Accepted: 2 July 2020; Published: 6 July 2020

check for updates

\begin{abstract}
During the host immune response, the precise balance of the immune system, regulated by immune checkpoint, is required to avoid infection and cancer. These immune checkpoints are the mainstream regulator of the immune response and are crucial for self-tolerance. During the last decade, various new immune checkpoint molecules have been studied, providing an attractive path to evaluate their potential role as targets for effective therapeutic interventions. Checkpoint inhibitors have mainly been explored in T cells until now, but natural killer (NK) cells are a newly emerging target for the determination of checkpoint molecules. Simultaneously, an increasing number of therapeutic dimensions have been explored, including modulatory and inhibitory checkpoint molecules, either causing dysfunction or promoting effector functions. Furthermore, the combination of the immune checkpoint with other NK cell-based therapeutic strategies could also strengthen its efficacy as an antitumor therapy. In this review, we have undertaken a comprehensive review of the literature to date regarding underlying mechanisms of modulatory and inhibitory checkpoint molecules.
\end{abstract}

Keywords: Natural killer cell (NK); cancer immunotherapy (CI); immune checkpoint costimulatory; immune therapeutics; modulatory immune checkpoint; inhibitory immune checkpoint

\section{Introduction}

Throughout evolution, innate immunity evolves earlier than adaptive immunity and is decisive for its exceptional line of defence in host immunity [1]. In the 1960s, a group of researchers aimed to investigate the T-cell mediated immune response, but accidentally discovered that there are naturally occurring cytotoxic lymphocytes other than T cells with antitumor properties [2]. Over the next several decades, researchers characterized this unexplored arm of the innate immune system known today as "Natural Killer (NK) Cells".

NK cells, as their name indicates, recognize malignant cells and perform natural cytotoxic functions along with the release of chemokines and cytokines, which further impact NK effector functions [3-6]. NK cells respond to germline-encoded markers of transformation present on the surface of cancer cells and regulate this recognition function via their activating and inhibitory receptors $[7,8]$. The first route of this cascade includes the expression of inhibitory receptors, which include three germ-line-encoded cell surface proteins: killer immunoglobulin-like receptors (KIRs), leukocyte immunoglobulin-like receptors, and CD94/NKG2A receptor belonging to c-type lectin superfamily (Figure 1) $[9,10]$. On the other hand, NK cells express a balance of germ-line-encoded activation receptors, which consist of natural cytotoxicity receptors (NCRs) such as NKp80, NKp46, NKp44, NKp30, and others; the c-type lectins, a superfamily of proteins that recognize a broad range of repertoire of ligands, such as NKG2D, 
NKG2C/CD94, 2B4, and NTB-A, and the CD16 (Fc $\gamma$ RIIIa), a type I transmembrane receptor containing two extracellular Ig-like domains, among others (Figure 2) [11].

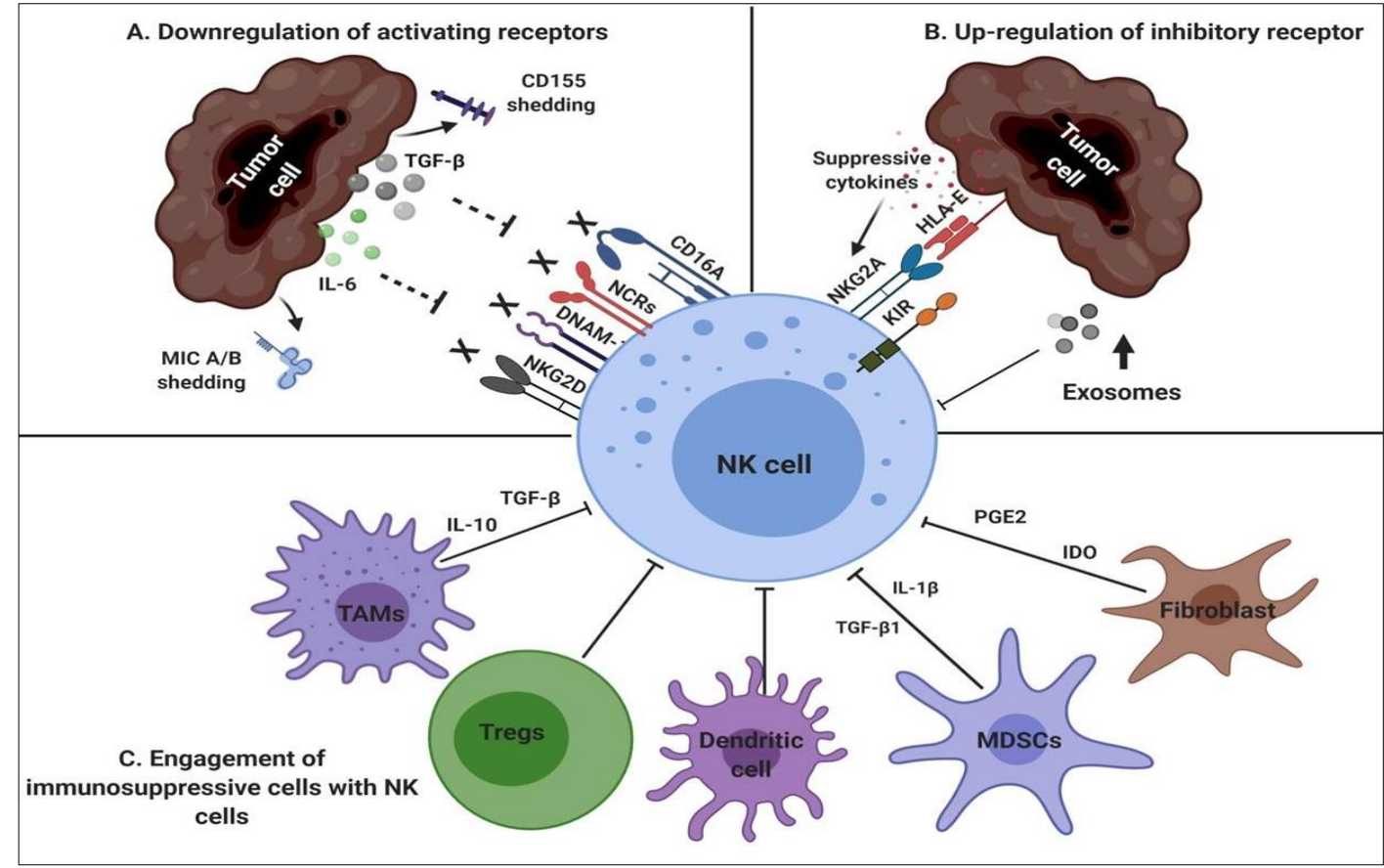

Figure 1. NK cell inhibitory mechanisms (A) Down-regulation of activating receptors on NK cells due to shedding of ligands such as CD155 or MIC A/B on tumor cells which impairs the activation of activating receptors and release of suppressive cytokines such as IL-6 and transforming growth factor-beta (TGF-ß), contribute to the formation of immunosuppressive tumor microenvironment; (B) Tumor cells up-regulate HLA-E ligand in order to escape from immune response which binds to NKG2A receptor and activate NK cell-inhibitory function and release of exosomes also blocks the NK cell activation; (C) Enrollment of immunosuppressive cells such as tumor-associated macrophages (TAMs), regulatory T cells (Tregs), Dendritic cells, myeloid derived supressor cells (MDSCs), fibroblast, suppress NK cells via suppressive cytokines.

Under malignant conditions, such as healthy cells transforming into cancer cells, stress ligands upregulate and cognately bind and activate NK receptors (Figure 2A). When activation signals dominate over inhibitory signals, NK cells activate protein tyrosine kinase (PTK)-dependent pathways and propagate the NK cell effector signalling pathways [12]. NK cells target malignant cells through an array of mechanisms. Despite these mechanisms, the malignant cells can evolve various escape routes, such as downregulation of adhesion molecules, a cognate ligand for activating receptors, or upregulation of major histocompatibility complex (MHC) molecules and secretion ofsome immunosuppressive cytokines such asinterleukin-10 (IL-10), transforming growth factor- $\beta$ (TGF- $\beta$ ), and indoleamine 2,3-dioxygenase (IDO) [13-15]. 


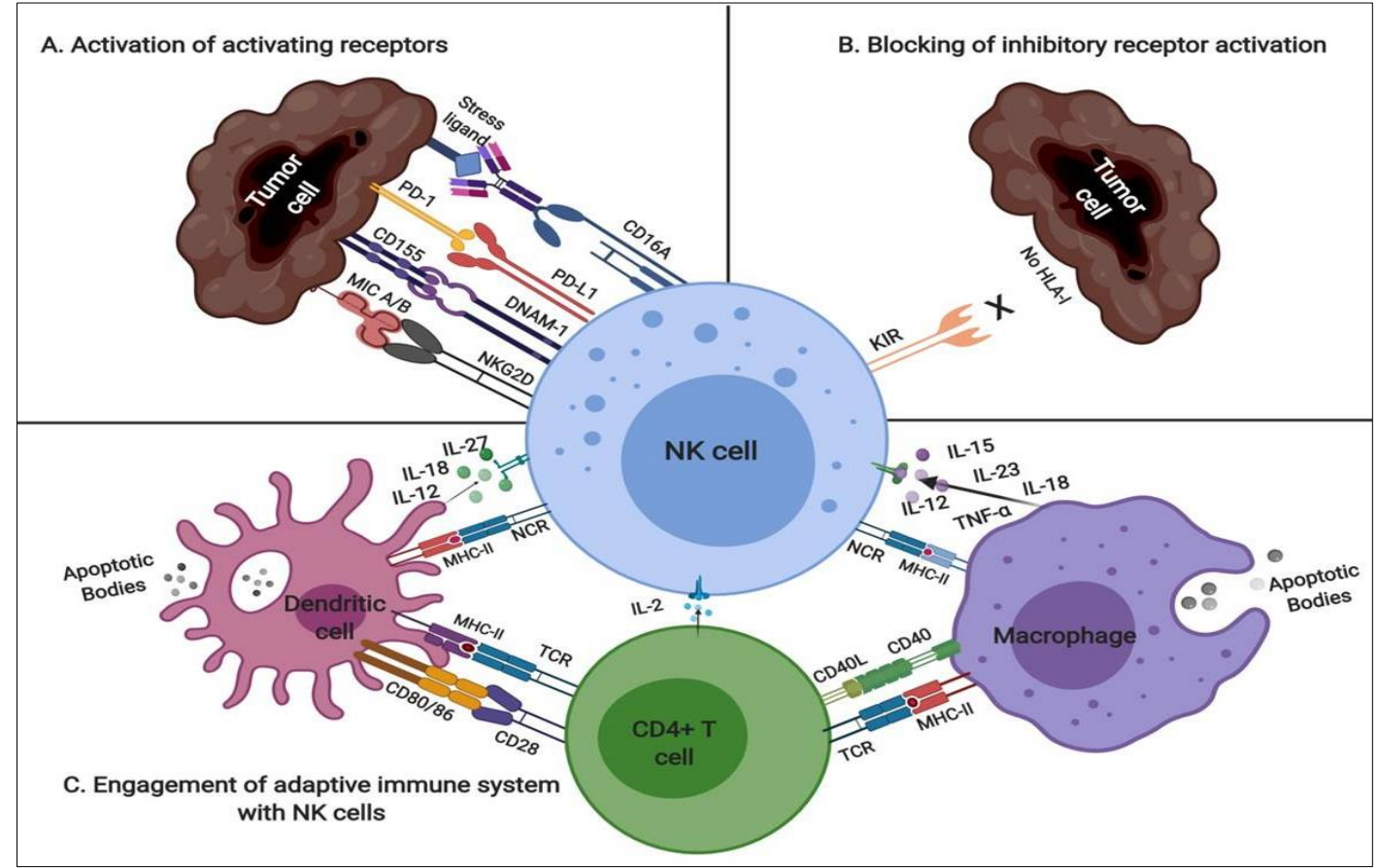

Figure 2. Schematic representation of NK cells-modulatory mechanism: (A) Mature NK cells express a range of germline-encoded activating and inhibitory receptors. The interaction of activating receptor of NK cells to their cognate ligand, either constitutively expressed or induced on tumor cells during transformation, activates the cytotoxic downstream signaling in NK cells; (B) As per the missing-self hypothesis, inhibitory receptor KIRs include KIR2DL1-3, KIR2DL5, and KIR3DL1-3, fails to engage with self-human leukocyte antigen (HLA) complex due to its absence and prevent the downstream inhibitory signaling; (C) The antigen-presenting cells (APCs) such as Macrophage and Dendritic cells process and present tumor antigen through MHC-II molecules and release distinct interleukin (IL) cytokines, encourage NK cells survival and activation; CD4+ T cell release IL-2 which is a potent inducer of NK cell proliferation and enhances cytotoxicity. (T-cell receptor (TCR), major histocompatibility complex class II molceules (MHC-II), natural cytotoxicity receptors (NCRs), tumor necrosis factor-alpha (TNF- $\alpha$ )).

\section{NK Cells as a Potential Therapeutic Strategy}

NK cells can eliminate both allogeneic and autologous malignant cells in vitro [16]. NK cells hold great potential, and understanding its mechanism of action or unravelling its exhausting mechanisms can play a crucial role in designing NK cell-based cellular therapy.

\subsection{NK Modulatory Mechanisms}

NK cells propagate their immune response through a complex cascade of receptors, and various strategies of NK cell activation are under consideration, including antibody cross-linking, soluble ligands, and monoclonal antibodies, such as targeting NKG2D [17] and NKp30 [18], stimulated dimierized soluble cytokine Interferon-gamma (IFN- $\gamma$ ) release by targeting 2B4 [19], and some costimulatory receptors such as CD137 [20]. Moreover, NK cells can mediate immune defence and actively lyse antibody-tagged target cells through engagement of the CD16A receptor and KIR detection of MHC class I ligand (HLA-I) (Figure 2A,B) [21]. Thus, targeting these activating receptors will promote NK cell effector and cytotoxic function and deplete target malignant cells.

In the tumor microenvironment (TME), an early phase of CD4+T cell (also known as Thelper cells) activation, induces IL-2 secretion, which leads to NK cell proliferation and enhances the cytotoxic activity of NK cells (Figure 2C) [22,23]. Mature dendritic cells (mDCs) and macrophages (M) are known as antigen-presenting cells (APC) that process and present tumor antigens to NK cells via MHC molecules [24,25]. Macrophages and mDCs release IL-23, IL-15, IL-12, IL-18, IL-27, and tumor necrosis 
factor-alpha (TNF- $\alpha$ ) cytokines, which induces the maturation and activation of cytotoxic NK cells (Figure 2C) [26-29]. During tumour growth, various intrinsic cellular mechanisms induce expression of several activating ligands, a direct link between cellular transformations, apoptosis, and surveillance by the immune system [30]. For instance, the DNA damage response (DDR) induces the expression of NKG2D ligands, such as MHC class I chain-related protein A and B (MIC A/B), and upregulates the DNAX accessory molecule-1 (DNAM-1) receptor-CD155 ligand pairing [31].

\subsection{NK-Suppressive Mechanisms}

NK cells are significant lymphocytes, and their dysfunction has a fundamental impact on disease progression and increases tumor incidence. Tumors evade the immune response by blocking activation pathways (Figure 1). They either release soluble factors such as IL-6 and TGF- $\beta$, which downregulates several activating receptors [32,33] (Figure 1A), or interact with inhibitory receptors, such as KIRs [34], through their ligand in order to escape from the immune response. However, several studies have observed the shedding of MIC A/B (NKG2D ligand) and CD155 (also known as poliovirus receptor (PVR)) (DNAM-1 ligand) from tumour cells (Figure 1A), which prevents NK cell activation and leads to NK cell hyporesponsiveness [35-38]. Moreover, TME creates hypoxia and releases exosomes that downregulate NK cell function (Figure 1B) [39].

Moreover, TME also releases TGF- $\beta$ and IFN- $\gamma$, and represses MIC A/B expression, which results in downmodulation of NKG2D expression, suppressing the cytotoxic ability of NK cells $[40,41]$. Proinflammatory or negatively regulated immune cells, myeloid-derived suppressor cells (MDSCs), dendritic cells, tumor-associated macrophages (TAMs), and regulatory T cells (Tregs) target NK cells and dampen NK cell activity through secretion of various suppressive cytokines (Figure 1C). MDSCs are capable of downregulating NK cell function through the release of TGF- $\beta 1$ and IL- $1 \beta[42,43]$, whereas TAMs release TGF- $\beta$ [44]. Moreover, Tregs can starve NK cells ofIL-2, seizing its growth, and tumor-associated fibroblasts generate Indoleamine 2, 3-dioxygenase (IDO) and Prostaglandin E2 (PGE2), which may block essential downstream NK cell activation signaling [45,46]. Similarly, DCs mediate inhibition of NK cells and require increased Signal transducer and activator of transcription 3 phosphorylation (pSTAT3) [47]. Indeed, NK cells recognize target cells without any prior activation, but malignant cells are capable of generating various ways to escape NK cell recognition and diminish their activity altogether. Subsequently, there is a new field of checkpoint receptors that regulate NK proliferation, activation, and inhibition, with growing attention towards their involvement as anticancer therapies. The therapeutic implications of the immune checkpoint molecules began by targeting inhibitory checkpoint molecules as a way of debulking tumors, but immune checkpoint costimulation has been highlighted as a target for anticancer therapies.

\section{Fundamental Mechanisms of Immune Checkpoints}

Immune checkpoints are proteins that regulate immune responses [48]. NK cells hold great potential, and unravelling these exhausting mechanisms will help play a crucial role in immunotherapy development. The concept of the immune checkpoint comes from the first proposal of anti-CTLA-4 (anti-cytotoxic T-lymphocyte-associated protein-4) as cancer immunotherapeutic target antigen in the late 1990s $[49,50]$. Further studies have revealed its dual functionality as both a stimulatory checkpoint and an inhibitory checkpoint [51]. Here, we discuss the recent advances in costimulator and inhibitor checkpoint molecules.

\subsection{Immune Checkpoint Costimulators}

NK cells propagate immune response through a complex cascade of receptors, and various strategies are under consideration, including the interaction of activating receptors to their cognate ligands, as well as dominant expression of activating receptors over inhibitory receptors. Recently, targeting immune checkpoints with a specific inhibitor antibody has revolutionized cancer treatment [52-54]. The application of immune checkpoint modification in the immunotherapy 
development has been explored in T cells, but checkpoint protein expression and functional significance in NK cells isless explored. In this review, we discuss the current knowledge of the expression of immune checkpoint protein of NK cells, and how they can modulate NK cell functions.

Several studies have identified costimulatory checkpoint molecules, including OX40 [55], CD357 [56], and 4-1BB [57,58] (Figure 3A). These costimulatory checkpoints on NK cells are bound by their cognate ligands from antigen-presenting cells (APCs) or tumor cells to convey proliferation, activation, or modulatory signals.

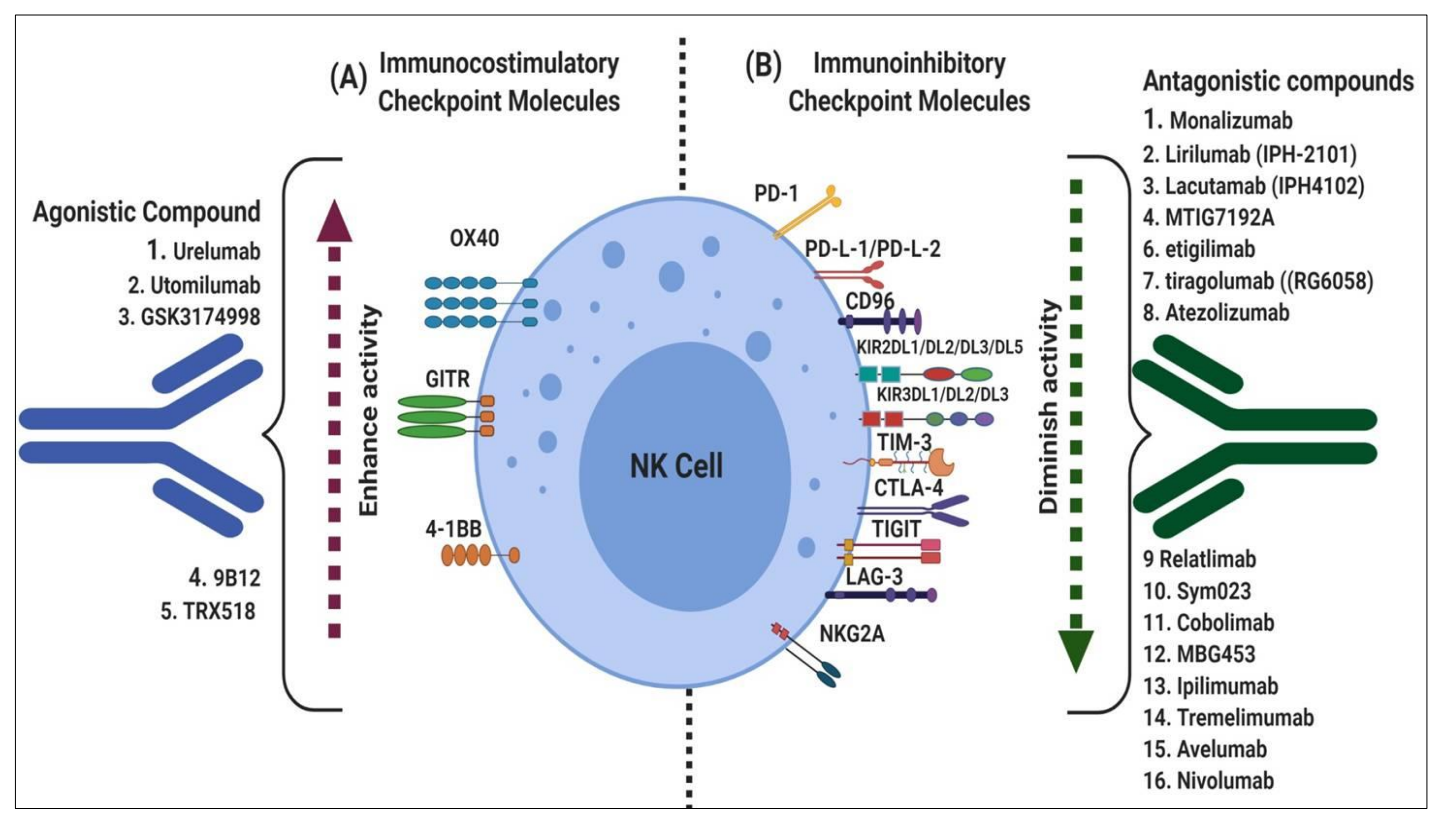

Figure 3. Immune-checkpoint molecules keep balance of the immune system: (A) Immunocostimulatory checkpoint receptors responsible for the enhanced immune cell proliferation, survival and activation and agonistic compound fully activates the receptor that it binds; (B) Immunoinhibitory checkpoint molecules diminish cell cytotoxic potential and prevent their antitumor functions and antagonistic compound that binds to a receptor but does not activate.

4-1BB (CD137 or tumor necrosis factor receptor superfamily 9/TNFSF9), is a costimulatory receptor expressed on activated immune cells, such as activated T cells and NK cells [57,59], and it interacts with its cognate ligand 4-1BBL, which is present on professional antigen-presenting cells (APCs), such as dendritic cells and monocytes/macrophages [60,61]. 4-1BB/4-1BBL crosslinking can induce either costimulatory signals, leading to proliferation, activation, and IL-2 production, or induce apoptosis ofT cells in order to deplete exhausted T cells [62-65]. Chen and colleagues intensively studied 4-1BB expression and its role in eradicating 4-1BBL-positive tumor cells in a murine model. They concluded that IL-2-activated NK 1.1 murine NK cells upregulate 4-1BB expression compared to non-activated NK cells [66]. Chen et al. also determined the direct impact of IL-2 and IL-15 cytokine exposure on the 4-1BB expression of murine NK cells, and showed that crosslinking of CD137 monoclonal antibody (mAb) leads to high levels of IFN- $\gamma$ secretion from NK cells [67]. Recently, human NK cells showed upregulation of the expression of 4-1BB in the presence of IL-2 and IL-15, but neither degranulation nor cytotoxicity increase demonstrated in human CD137+ NK cells [57]. Bidirectional signalling through CD137/CD137L is critical in modulating immunomodulatory functions, including the production of proinflammatory cytokines and chemokines in APCs, which attracts neutrophils. Activation of T and NK cells can influence other immunomodulatory immune cells, and CD137/CD137L signalling can also regulate functions of dendritic cells and Tregs [57,59,68-72]. In preclinical studies, the synergistic approach of anti-CD20 mAb and anti-CD137 mAb induced an effective NK-mediated antibody-dependent cellular cytotoxicity (ADCC) against lymphoma malignant cells [73]. There has been significant progress made 
in recent years in exposing the expression, function, and therapeutic potential of 4-1BB. Targeting 4-1BB with an agonistic mAb revealed potent antitumour effects in murine tumor models [74]. Currently, a combinatorial approach to synergistically combine 4-1BB therapy with approved tumor-targeted mAbs, such as a combination of Rituximab (anti-CD20 mAbs) and an agonistic 4-1BB antibody, which promotes cytokine production and enhanced tumor clearance [67,75]. Targeting of CD137 augmented the therapeutic efficacy of direct-targeting mAbs, such as Rituximab (anti-CD20) [76], Trastuzumab (anti-HER2/ human epidermal growth factor receptor 2) [77], and Cetuximab (anti-epidermal growth factor receptor (anti-EGFR)) [78], in hematological and solid tumor models. Urelumab (BMS-663513), a human IgG4 mAb was the first 4-1BB-targeting antibody to enter the clinic [79]. Initially, Urelumab showed moderate dose-dependent toxicity in phase 1 and 2 results, but later was included in trials with Rituximab, Cetuximab, Elotuzumab, and Nivolumab (NCT01471210, NCT01775631, NCT02110082, NCT02252263, and NCT02253992) (Table 1). Pfizer, New York (United States) developed a humanized IgG2 mAb agonist of the T cell costimulatory receptor 4-1BB/CD137 (Utomilumab; PF-05082566) that activates 4-1BB and blocks 4-1BBL endogenous binding. Initial clinical data with Utomilumab has shown superior safety and efficacy compared to Urelumab [80]. In 2016, Utomilumab, in combination with the humanized, (programmed cell death protein-1/PD-1-blocking IgG4 mAb Pembrolizumab, was evaluated in a phase $1 \mathrm{~b}$ trial and demonstrated clinical benefit with two complete responses and four partial responses out of 23 patients with advanced solid tumor, and showed no significant toxicity [81]. Despite the broad expression of 4-1BB/4-1BBL and its distinct involvement in immune dynamics, the therapeutic efficacy relies directly on activated T cells and indirectly on NK cells, and can be further modified using a synergistic approach. 
Table 1. Clinical trials combining checkpoint receptor based targeting with or without biologicals

\begin{tabular}{cccccccc}
\hline $\begin{array}{c}\text { Receptor/Target } \\
\text { Antigen }\end{array}$ & Drugs/Interventions & $\begin{array}{c}\text { Combinations } \\
\text { (Drug, Biologics) }\end{array}$ & Disease & $\begin{array}{c}\text { Clinical Trials, } \\
\text { Allocation }\end{array}$ & Study Title & Participants & Status \\
\hline Identifier
\end{tabular}


Table 1. Cont

\begin{tabular}{|c|c|c|c|c|c|c|c|c|c|}
\hline $\begin{array}{c}\text { Receptor/Target } \\
\text { Antigen }\end{array}$ & Drugs /Interventions & $\begin{array}{c}\text { Combinations } \\
\text { (Drug, Biologics) }\end{array}$ & Disease & $\begin{array}{l}\text { Clinical Trials, } \\
\text { Allocation }\end{array}$ & Study Title & Participants & Status & Sponsors & $\begin{array}{c}\text { Clinical Trials } \\
\text { Identifier } \\
\end{array}$ \\
\hline \multirow{7}{*}{ OX40 (CD134) } & $\begin{array}{l}\text { Anti-OX40 Antibody BMS } \\
986178\end{array}$ & $\begin{array}{l}\text { TLR9 Agonist } \\
\text { SD-101 }\end{array}$ & Neoplasms & Phase 1, N/A & $\begin{array}{l}\text { SD-101 and BMS-986178 in } \\
\text { Treating Patients With Advanced } \\
\text { or Metastatic Solid Malignancies }\end{array}$ & 27 & Recruiting & Ronald Levy & NCT03831295 \\
\hline & $\begin{array}{l}\text { anti-OX40 murine monoclonal } \\
\text { antibody, MEDI } 6469\end{array}$ & Single agent & $\begin{array}{l}\text { Head and Neck } \\
\text { Cancer }\end{array}$ & $\begin{array}{c}\text { Phase 1, } \\
\text { Nonrandomized }\end{array}$ & $\begin{array}{l}\text { Anti-OX40 Antibody in Head } \\
\text { and Neck Cancer Patients }\end{array}$ & 17 & $\begin{array}{c}\text { Active, not } \\
\text { recruiting }\end{array}$ & $\begin{array}{l}\text { Providence Health \& } \\
\text { Services }\end{array}$ & NCT02274155 \\
\hline & $\begin{array}{l}\text { Anti-OX40 Antibody } \\
\text { PF-04518600 }\end{array}$ & $\begin{array}{l}\text { Avelumab, } \\
\text { Binimetinib, } \\
\text { Utomilumab }\end{array}$ & Breast Carcinoma & $\begin{array}{c}\text { Phase 2, } \\
\text { Randomized }\end{array}$ & $\begin{array}{l}\text { Avelumab With Binimetinib, } \\
\text { Utomilumab, or Anti-OX40 } \\
\text { Antibody PF-04518600 in } \\
\text { Treating Triple Negative Breast } \\
\text { Cancer }\end{array}$ & 150 & Recruiting & Hope Rugo, MD & NCT03971409 \\
\hline & GSK3174998 & Pembrolizumab & Neoplasms & $\begin{array}{l}\text { Phase 1, } \\
\text { Nonrandomized }\end{array}$ & $\begin{array}{l}\text { GSK3174998 Alone or With } \\
\text { Pembrolizumab in Subjects With } \\
\text { Advanced Solid Tumors } \\
\text { (ENGAGE-1) }\end{array}$ & 142 & Completed & GlaxoSmithKline & NCT02528357 \\
\hline & MOXR0916 & Single agent & Neoplasms & $\begin{array}{c}\text { Phase 1, } \\
\text { Nonrandomized }\end{array}$ & $\begin{array}{c}\text { A Study to Assess Safety and } \\
\text { Pharmacokinetics of MOXR0916 } \\
\text { in Participants With Locally } \\
\text { Advanced or Metastatic Solid } \\
\text { Tumors } \\
\end{array}$ & 174 & Completed & Genentech, Inc. & NCT02219724 \\
\hline & anti-OX40 & $\begin{array}{c}\text { Radiation: } \\
\text { Radiation, } \\
\text { Cyclophosphamide }\end{array}$ & Prostate Cancer & $\begin{array}{l}\text { Phase 1, } \\
\text { Nonrandomized }\end{array}$ & $\begin{array}{c}\text { Anti-OX40, Cyclophosphamide } \\
\text { (CTX) and Radiation in Patients } \\
\text { With Progressive Metastatic } \\
\text { Prostate Cancer }\end{array}$ & 13 & Completed & $\begin{array}{l}\text { Providence Health \& } \\
\text { Services }\end{array}$ & NCT01303705 \\
\hline & anti-OX40 & $\begin{array}{c}\text { Biological: } \\
\text { Tetanus vaccine } \\
\text { Biological: KLH }\end{array}$ & Advanced Cancer & $\begin{array}{c}\text { Phase 1, } \\
\text { Randomized }\end{array}$ & $\begin{array}{l}\text { Phase } 1 \text { Study of anti-OX40 in } \\
\text { Patients With Advanced Cancer }\end{array}$ & 30 & Completed & $\begin{array}{l}\text { Providence Health \& } \\
\text { Services }\end{array}$ & NCT01644968 \\
\hline
\end{tabular}


Table 1. Cont

\begin{tabular}{|c|c|c|c|c|c|c|c|c|c|}
\hline $\begin{array}{l}\text { Receptor/Target } \\
\text { Antigen }\end{array}$ & Drugs/Interventions & $\begin{array}{c}\text { Combinations } \\
\text { (Drug, Biologics) }\end{array}$ & Disease & $\begin{array}{l}\text { Clinical Trials, } \\
\text { Allocation }\end{array}$ & Study Title & Participants & Status & Sponsors & $\begin{array}{c}\text { Clinical Trials } \\
\text { Identifier }\end{array}$ \\
\hline \multirow{6}{*}{ GITR/GITRL } & Biological: TRX518 & $\mathrm{N} / \mathrm{A}$ & $\begin{array}{c}\text { Unresectable Stage III } \\
\text { or Stage IV Malignant } \\
\text { Melanoma or Other } \\
\text { Solid tumor } \\
\text { malignancies }\end{array}$ & Phase 1, N/A & $\begin{array}{l}\text { Trial of TRX518 (Anti-GITR } \\
\text { mAb) in Stage III or IV } \\
\text { Malignant Melanoma or Other } \\
\text { Solid Tumors (TRX518-001) }\end{array}$ & 10 & Completed & $\begin{array}{l}\text { Leap Therapeutics, } \\
\text { Inc. }\end{array}$ & NCT01239134 \\
\hline & $\begin{array}{l}\text { Anti-GITR Agonistic Monoclonal } \\
\text { Antibody BMS-986156 }\end{array}$ & $\begin{array}{l}\text { Ipilimumab, } \\
\text { Nivolumab, } \\
\text { Radiation: } \\
\text { Stereotactic Body, } \\
\text { Radiation } \\
\text { Therapy }\end{array}$ & $\begin{array}{l}\text { Neoplasms \& Lung } \\
\text { carcinoma }\end{array}$ & $\begin{array}{c}\text { Phase 1, 2, } \\
\text { Nonrandomized }\end{array}$ & $\begin{array}{l}\text { BMS-986156, Ipilimumab, and } \\
\text { Nivolumab With or Without } \\
\text { Stereotactic Body Radiation } \\
\text { Therapy in Treating Patients } \\
\text { With Advanced or Metastatic } \\
\text { Lung/Chest or Liver Cancers }\end{array}$ & 60 & Recruiting & $\begin{array}{l}\text { M.D. Anderson } \\
\text { Cancer Center }\end{array}$ & NCT04021043 \\
\hline & MEDI1873 & Single agent & $\begin{array}{l}\text { Advanced solid } \\
\text { tumor }\end{array}$ & Phase 1, N/A & $\begin{array}{l}\text { A Study in Adult Subjects With } \\
\text { Select Advanced Solid Tumors }\end{array}$ & 40 & Completed & MedImmune LLC & NCT02583165 \\
\hline & $\begin{array}{l}\text { anti-GITR agonistic monoclonal } \\
\text { antibody ASP1951 }\end{array}$ & Pembrolizumab & $\begin{array}{l}\text { Advanced solid } \\
\text { tumor }\end{array}$ & $\begin{array}{l}\text { Phase 1, } \\
\text { Nonrandomized }\end{array}$ & $\begin{array}{l}\text { A Study of ASP1951 in Subjects } \\
\text { With Advanced Solid Tumors }\end{array}$ & 435 & Recruiting & $\begin{array}{l}\text { Astellas Pharma } \\
\text { Global Development, } \\
\text { Inc. }\end{array}$ & NCT03799003 \\
\hline & GWN323 (Anti-GITR) & PDR001 & Solid tumor & $\begin{array}{l}\text { Phase 1, } \\
\text { Nonrandomized }\end{array}$ & $\begin{array}{c}\text { Phase I/lb Study of GWN323 } \\
\text { Alone and in Combination With } \\
\text { PDR001 in Patients With } \\
\text { Advanced Malignancies and } \\
\text { Lymphomas } \\
\end{array}$ & 92 & Completed & $\begin{array}{c}\text { Novartis } \\
\text { Pharmaceuticals }\end{array}$ & NCT02740270 \\
\hline & BMS-986156 & Nivolumab & Solid tumor & $\begin{array}{l}\text { Phase 1, 2, } \\
\text { Nonrandomized }\end{array}$ & $\begin{array}{c}\text { An Investigational } \\
\text { Immuno-therapy Study of } \\
\text { Experimental Medication } \\
\text { BMS-986156, Given by Itself or in } \\
\text { Combination With Nivolumab in } \\
\text { Patients With Solid Cancers or } \\
\text { Cancers That Have Spread. }\end{array}$ & 331 & $\begin{array}{l}\text { Active, not } \\
\text { recruiting }\end{array}$ & Bristol-Myers Squibb & NCT02598960 \\
\hline
\end{tabular}


Table 1. Cont

\begin{tabular}{|c|c|c|c|c|c|c|c|c|c|}
\hline $\begin{array}{c}\text { Receptor/Target } \\
\text { Antigen }\end{array}$ & Drugs/Interventions & $\begin{array}{c}\text { Combinations } \\
\text { (Drug, Biologics) }\end{array}$ & Disease & $\begin{array}{c}\text { Clinical Trials, } \\
\text { Allocation }\end{array}$ & Study Title & Participants & Status & Sponsors & $\begin{array}{c}\text { Clinical Trials } \\
\text { Identifier }\end{array}$ \\
\hline \multirow{6}{*}{ NKG2A } & \multirow{6}{*}{ Monalizumab (IPH2201) } & Single agent & Gynecologic Cancer & Phase $1, \mathrm{~N} / \mathrm{A}$ & $\begin{array}{l}\text { A Dose-Ranging Study of } \\
\text { IPH2201 in Patients With } \\
\text { Gynecologic Malignancies }\end{array}$ & 59 & Completed & $\begin{array}{l}\text { Canadian Cancer } \\
\text { Trials Group }\end{array}$ & NCT02459301 \\
\hline & & Single agent & $\begin{array}{l}\text { Hematologic } \\
\text { Malignancies }\end{array}$ & Phase 1, N/A & $\begin{array}{l}\text { Study of a Humanized Antibody } \\
\text { Initiated } 2 \text { Months After an HLA } \\
\text { Matched Allogenic Stem Cell } \\
\text { Transplantation (PIRAT) }\end{array}$ & 18 & Recruiting & $\begin{array}{c}\text { Institut } \\
\text { Paoli-Calmettes }\end{array}$ & NCT02921685 \\
\hline & & $\begin{array}{l}\text { Cetuximab, } \\
\text { Anti-PD-L1 }\end{array}$ & $\begin{array}{l}\text { Head and Neck } \\
\text { Neoplasms }\end{array}$ & $\begin{array}{c}\text { Phase 1, 2, } \\
\text { Nonrandomized }\end{array}$ & $\begin{array}{l}\text { Study of Monalizumab and } \\
\text { Cetuximab in Patients With } \\
\text { Recurrent or Metastatic } \\
\text { Squamous Cell Carcinoma of the } \\
\text { Head and Neck }\end{array}$ & 140 & Recruiting & Innate Pharma & NCT02643550 \\
\hline & & $\begin{array}{l}\text { Durvalumab } \\
\text { (MEDI4736) }\end{array}$ & $\begin{array}{l}\text { Advanced solid } \\
\text { tumor }\end{array}$ & $\begin{array}{c}\text { Phase 1, 2, } \\
\text { Nonrandomized }\end{array}$ & $\begin{array}{c}\text { A Study of Durvalumab } \\
\text { (MEDI4736) and Monalizumab } \\
\text { in Solid Tumors }\end{array}$ & 383 & $\begin{array}{l}\text { Active, not } \\
\text { recruiting }\end{array}$ & MedImmune LLC & NCT02671435 \\
\hline & & $\begin{array}{c}\text { Afatinib, } \\
\text { Palbociclib, } \\
\text { standard of } \\
\text { care,IPH2201, } \\
\text { Durvalumab, } \\
\text { Niraparib, } \\
\text { BAY1163877 }\end{array}$ & $\begin{array}{l}\text { Carcinoma, } \\
\text { Squamous Cell of } \\
\text { Head and Neck }\end{array}$ & $\begin{array}{c}\text { Phase 2, } \\
\text { Nonrandomized }\end{array}$ & $\begin{array}{l}\text { Biomarker-based Study in } \\
\text { recurrent or metastatic } \\
\text { squamous cell carcinoma of the } \\
\text { head and neck (UPSTREAM) }\end{array}$ & 340 & Recruiting & $\begin{array}{l}\text { European } \\
\text { Organisation for } \\
\text { Research and } \\
\text { Treatment of Cancer - } \\
\text { EORTC }\end{array}$ & NCT03088059 \\
\hline & & $\begin{array}{c}\text { Durvalumab + } \\
\text { Oleclumab }\end{array}$ & $\begin{array}{l}\text { Stage III Non-small } \\
\text { Cell Lung Cancer } \\
\text { Unresectable }\end{array}$ & $\begin{array}{c}\text { Phase 2, } \\
\text { Randomized }\end{array}$ & $\begin{array}{l}\text { Durvalumab Alone or in } \\
\text { Combination With Novel Agents } \\
\text { in Subjects With NSCLC } \\
\text { (COAST) }\end{array}$ & 300 & Recruiting & MedImmune LLC & NCT03822351 \\
\hline
\end{tabular}


Table 1. Cont

\begin{tabular}{|c|c|c|c|c|c|c|c|c|c|}
\hline $\begin{array}{l}\text { Receptor/Target } \\
\text { Antigen }\end{array}$ & Drugs /Interventions & $\begin{array}{c}\text { Combinations } \\
\text { (Drug, Biologics) }\end{array}$ & Disease & $\begin{array}{l}\text { Clinical Trials, } \\
\text { Allocation }\end{array}$ & Study Title & Participants & Status & Sponsors & $\begin{array}{c}\text { Clinical Trials } \\
\text { Identifier }\end{array}$ \\
\hline & Anti-KIR (1-7F9) & Single agent & Multiple Myeloma & Phase 1, N/A & $\begin{array}{l}\text { An Open-label, Dose-escalation } \\
\text { Safety and Tolerability Trial } \\
\text { Assessing Anti-KIR (1-7F9) in } \\
\text { Subjects With Multiple Myeloma }\end{array}$ & 32 & Completed & Innate Pharma & NCT00552396 \\
\hline & \multirow{4}{*}{$\begin{array}{l}\text { IPH2101, a human monoclonal } \\
\text { anti-KIR antibody }\end{array}$} & Single agent & Multiple Myeloma & $\begin{array}{c}\text { Phase 2, } \\
\text { Randomized }\end{array}$ & $\begin{array}{c}\text { Evaluation of Activity, Safety } \\
\text { and Pharmacology of IPH2101 a } \\
\text { Human Monoclonal Antibody in } \\
\text { Patients With Multiple Myeloma } \\
\text { (REMYKIR) }\end{array}$ & 27 & Completed & Innate Pharma & NCT00999830 \\
\hline & & Single agent & $\begin{array}{l}\text { Acute myeloid } \\
\text { leukemia }\end{array}$ & $\begin{array}{c}\text { Phase 1, } \\
\text { Nonrandomized }\end{array}$ & $\begin{array}{c}\text { A Safety and Tolerability } \\
\text { Extension Trial Assessing } \\
\text { Repeated Dosing of Anti-KIR } \\
\text { (1-7F9) Human Monoclonal } \\
\text { Antibody in Patients With Acute } \\
\text { Myeloid Leukaemia }\end{array}$ & 21 & Completed & Innate Pharma & NCT01256073 \\
\hline & & Single agent & $\begin{array}{l}\text { Smoldering Multiple } \\
\text { Myeloma }\end{array}$ & $\begin{array}{c}\text { Phase 2, } \\
\text { Randomized }\end{array}$ & $\begin{array}{l}\text { Study on the Anti-tumor } \\
\text { Activity, Safety and } \\
\text { Pharmacology of IPH2101 in } \\
\text { Patients With Smoldering } \\
\text { Multiple Myeloma (KIRMONO) }\end{array}$ & 30 & Completed & Innate Pharma & NCT01222286 \\
\hline & & Lenalidomide & $\begin{array}{l}\text { Relapsed Multiple } \\
\text { Myeloma }\end{array}$ & $\begin{array}{c}\text { Phase 1, } \\
\text { Nonrandomized }\end{array}$ & $\begin{array}{l}\text { Study on the Safety, Anti-tumor } \\
\text { Activity and Pharmacology of } \\
\text { IPH2101 Combined With } \\
\text { Lenalidomide in Patients With } \\
\text { Multiple Myeloma Experiencing } \\
\text { a First or Second Relapse } \\
\text { (KIRIMID) }\end{array}$ & 15 & Completed & Innate Pharma & NCT01217203 \\
\hline & $\begin{array}{l}\text { Lirilumab } \\
\text { (IPH2102/BMS-986015) }\end{array}$ & Placebo & $\begin{array}{l}\text { Acute myeloid } \\
\text { leukemia }\end{array}$ & $\begin{array}{c}\text { Phase 2, } \\
\text { Randomized }\end{array}$ & $\begin{array}{c}\text { Efficacy Study of Anti-KIR } \\
\text { Monoclonal Antibody as } \\
\text { Maintenance Treatment in Acute } \\
\text { Myeloid Leukemia (EFFIKIR) } \\
\text { (EFFIKIR) } \\
\end{array}$ & 152 & Completed & Innate Pharma & NCT01687387 \\
\hline
\end{tabular}


Table 1. Cont

\begin{tabular}{|c|c|c|c|c|c|c|c|c|c|}
\hline $\begin{array}{c}\text { Receptor/Target } \\
\text { Antigen }\end{array}$ & Drugs /Interventions & $\begin{array}{c}\begin{array}{c}\text { Combinations } \\
\text { (Drug, Biologics) }\end{array} \\
\end{array}$ & Disease & $\begin{array}{c}\text { Clinical Trials, } \\
\text { Allocation }\end{array}$ & Study Title & Participants & Status & Sponsors & $\begin{array}{c}\text { Clinical Trials } \\
\text { Identifier }\end{array}$ \\
\hline \multirow[t]{7}{*}{ KIR } & \multirow{5}{*}{ Lirilumab (BMS-986015) } & Ipilimumab & $\begin{array}{c}\text { Cancer, } \\
\text { (not-otherwise } \\
\text { specified) NOS }\end{array}$ & $\begin{array}{l}\text { Phase 1, } \\
\text { Nonrandomized }\end{array}$ & $\begin{array}{l}\text { Safety Study of BMS-986015 } \\
\text { (Anti-KIR) in Combination With } \\
\text { Ipilimumab in Subjects With } \\
\text { Selected Advanced Tumor }\end{array}$ & 22 & Completed & Bristol-Myers Squibb & NCT01750580 \\
\hline & & $\begin{array}{l}\text { Elotuzumab, } \\
\text { Urelumab }\end{array}$ & Multiple Myeloma & $\begin{array}{c}\text { Phase 1, } \\
\text { Randomized }\end{array}$ & $\begin{array}{l}\text { A Phase I Open Label Study of } \\
\text { the Safety and Tolerability of } \\
\text { Elotuzumab (BMS-901608) } \\
\text { Administered in Combination } \\
\text { With Either Lirilumab } \\
\text { (BMS-986015) or Urelumab } \\
\text { (BMS-663513) in Subjects With } \\
\text { Multiple Myeloma }\end{array}$ & 44 & Completed & Bristol-Myers Squibb & NCT02252263 \\
\hline & & Rituximab & Leukemia & $\begin{array}{c}\text { Phase 2, } \\
\text { Nonrandomized }\end{array}$ & $\begin{array}{l}\text { Lirilumab With Rituximab for } \\
\text { Relapsed, Refractory or } \\
\text { High-risk Untreated Chronic } \\
\text { Lymphocytic Leukemia (CLL) } \\
\text { Patients }\end{array}$ & 7 & Completed & $\begin{array}{l}\text { M.D. Anderson } \\
\text { Cancer Center }\end{array}$ & NCT02481297 \\
\hline & & $\begin{array}{l}\text { Nivolumab, } \\
\text { Ipilimumab }\end{array}$ & Advanced Cancer & $\begin{array}{l}\text { Phase 1, } \\
\text { Nonrandomized }\end{array}$ & $\begin{array}{l}\text { A Safety Study of Lirilumab in } \\
\text { Combination With Nivolumab or } \\
\text { in Combination With Nivolumab } \\
\text { and Ipilimumab in Advanced } \\
\text { and/or Metastatic Solid Tumors }\end{array}$ & 21 & $\begin{array}{l}\text { Active, not } \\
\text { recruiting }\end{array}$ & Bristol-Myers Squibb & NCT03203876 \\
\hline & & $\begin{array}{l}\text { Nivolumab, } \\
\text { Ipilimumab }\end{array}$ & Cancer, NOS & $\begin{array}{c}\text { Phase 1,2 } \\
\text { Randomized }\end{array}$ & $\begin{array}{l}\text { A Study of an Anti-KIR } \\
\text { Antibody Lirilumab in } \\
\text { Combination With an Anti-PD-1 } \\
\text { Antibody Nivolumab and } \\
\text { Nivolumab Plus an Anti-CTLA-4 } \\
\text { Ipilimumab Antibody in Patients } \\
\text { With Advanced Solid Tumors }\end{array}$ & 337 & Completed & Bristol-Myers Squibb & NCT01714739 \\
\hline & \multirow[b]{2}{*}{ IPH4102 } & Single agent & $\begin{array}{l}\text { Cutaneous T cell } \\
\text { Lymphoma }\end{array}$ & Phase 1, N/A & $\begin{array}{l}\text { Study of IPH4102 in Patients } \\
\text { With Relapsed/Refractory } \\
\text { Cutaneous T cell Lymphomas } \\
\text { (CTCL) }\end{array}$ & 60 & $\begin{array}{l}\text { Active, not } \\
\text { recruiting }\end{array}$ & Innate Pharma & NCT02593045 \\
\hline & & $\begin{array}{c}\text { Gemcitabine + } \\
\text { Oxaliplatin }\end{array}$ & T cell lymphoma & $\begin{array}{c}\text { Phase 2, } \\
\text { Nonrandomized }\end{array}$ & $\begin{array}{c}\text { IPH4102 Alone or in } \\
\text { Combination With } \\
\text { Chemotherapy in Patients With } \\
\text { Advanced T Cell Lymphoma } \\
\text { (TELLOMAK) }\end{array}$ & 250 & Recruiting & Innate Pharma & NCT03902184 \\
\hline
\end{tabular}


Table 1. Cont

\begin{tabular}{|c|c|c|c|c|c|c|c|c|c|}
\hline $\begin{array}{c}\text { Receptor/Target } \\
\text { Antigen }\end{array}$ & Drugs /Interventions & $\begin{array}{c}\text { Combinations } \\
\text { (Drug, Biologics) }\end{array}$ & Disease & $\begin{array}{c}\text { Clinical Trials, } \\
\text { Allocation }\end{array}$ & Study Title & Participants & Status & Sponsors & $\begin{array}{c}\text { Clinical Trials } \\
\text { Identifier }\end{array}$ \\
\hline \multirow{5}{*}{ TIGIT } & \multirow[t]{2}{*}{ MTIG7192A (anti-TIGIT mAb) } & $\begin{array}{l}\text { Atezolizumab, } \\
\text { Carboplatin, } \\
\text { Cisplatin, } \\
\text { Pemetrexed, } \\
\text { Paclitaxel, } \\
\text { Etoposide }\end{array}$ & $\begin{array}{c}\text { Advanced/Metastatic } \\
\text { Tumors }\end{array}$ & $\begin{array}{c}\text { Phase 1, } \\
\text { Nonrandomized }\end{array}$ & $\begin{array}{l}\text { Safety and Pharmacokinetics } \\
\text { (PK) of Escalating Doses of } \\
\text { MTIG7192A as a Single Agent } \\
\text { and in Combination With } \\
\text { Atezolizumab With and Without } \\
\text { Chemotherapy in Locally } \\
\text { Advanced or Metastatic Tumors }\end{array}$ & 400 & Recruiting & Genentech, Inc. & NCT02794571 \\
\hline & & $\begin{array}{l}\text { Atezolizumab, } \\
\text { Placebo }\end{array}$ & $\begin{array}{c}\text { Non-small Cell Lung } \\
\text { Cancer }\end{array}$ & $\begin{array}{c}\text { Phase 2, } \\
\text { Randomized }\end{array}$ & $\begin{array}{c}\text { A Study of MTIG7192A in } \\
\text { Combination With Atezolizumab } \\
\text { in Chemotherapy-Naïve Patients } \\
\text { With Locally Advanced or } \\
\text { Metastatic Non-Small Cell Lung } \\
\text { Cancer } \\
\end{array}$ & 135 & $\begin{array}{l}\text { Active, not } \\
\text { recruiting }\end{array}$ & Genentech, Inc. & NCT03563716 \\
\hline & \multirow[b]{2}{*}{ Tiragolumab } & $\begin{array}{l}\text { Atezolizumab, } \\
\text { Carboplatin, } \\
\text { Etoposide, } \\
\text { Placebo }\end{array}$ & Small cell lung cancer & $\begin{array}{c}\text { Phase 3, } \\
\text { Randomized }\end{array}$ & $\begin{array}{l}\text { A Study of Atezolizumab Plus } \\
\text { Carboplatin and Etoposide With } \\
\text { or Without Tiragolumab in } \\
\text { Patients With Untreated } \\
\text { Extensive-Stage Small Cell Lung } \\
\text { Cancer (SKYSCRAPER-02) }\end{array}$ & 400 & Recruiting & Hoffmann-La Roche & NCT04256421 \\
\hline & & $\begin{array}{l}\text { Atezolizumab, } \\
\text { Matching Placebo }\end{array}$ & $\begin{array}{c}\text { Non-small Cell Lung } \\
\text { Cancer }\end{array}$ & $\begin{array}{c}\text { Phase 3, } \\
\text { Randomized }\end{array}$ & $\begin{array}{l}\text { A Study of Tiragolumab in } \\
\text { Combination With Atezolizumab } \\
\text { Compared With Placebo in } \\
\text { Combination With Atezolizumab } \\
\text { in Patients With Previously } \\
\text { Untreated Locally Advanced } \\
\text { Unresectable or Metastatic } \\
\text { PD-L1-Selected Non-Small Cell } \\
\text { Lung Cancer (SKYSCRAPER-01) }\end{array}$ & 500 & Recruiting & Hoffmann-La Roche & NCT04294810 \\
\hline & AB154 (anti-TIGIT mAb) & AB122 & Solid Tumor & $\begin{array}{c}\text { Phase 1, } \\
\text { Nonrandomized }\end{array}$ & $\begin{array}{l}\text { A Study to Evaluate the Safety } \\
\text { and Tolerability of AB154 in } \\
\text { Participants With Advanced } \\
\text { Malignancies }\end{array}$ & 66 & Recruiting & $\begin{array}{l}\text { Arcus Biosciences, } \\
\text { Inc. }\end{array}$ & NCT03628677 \\
\hline
\end{tabular}


Table 1. Cont

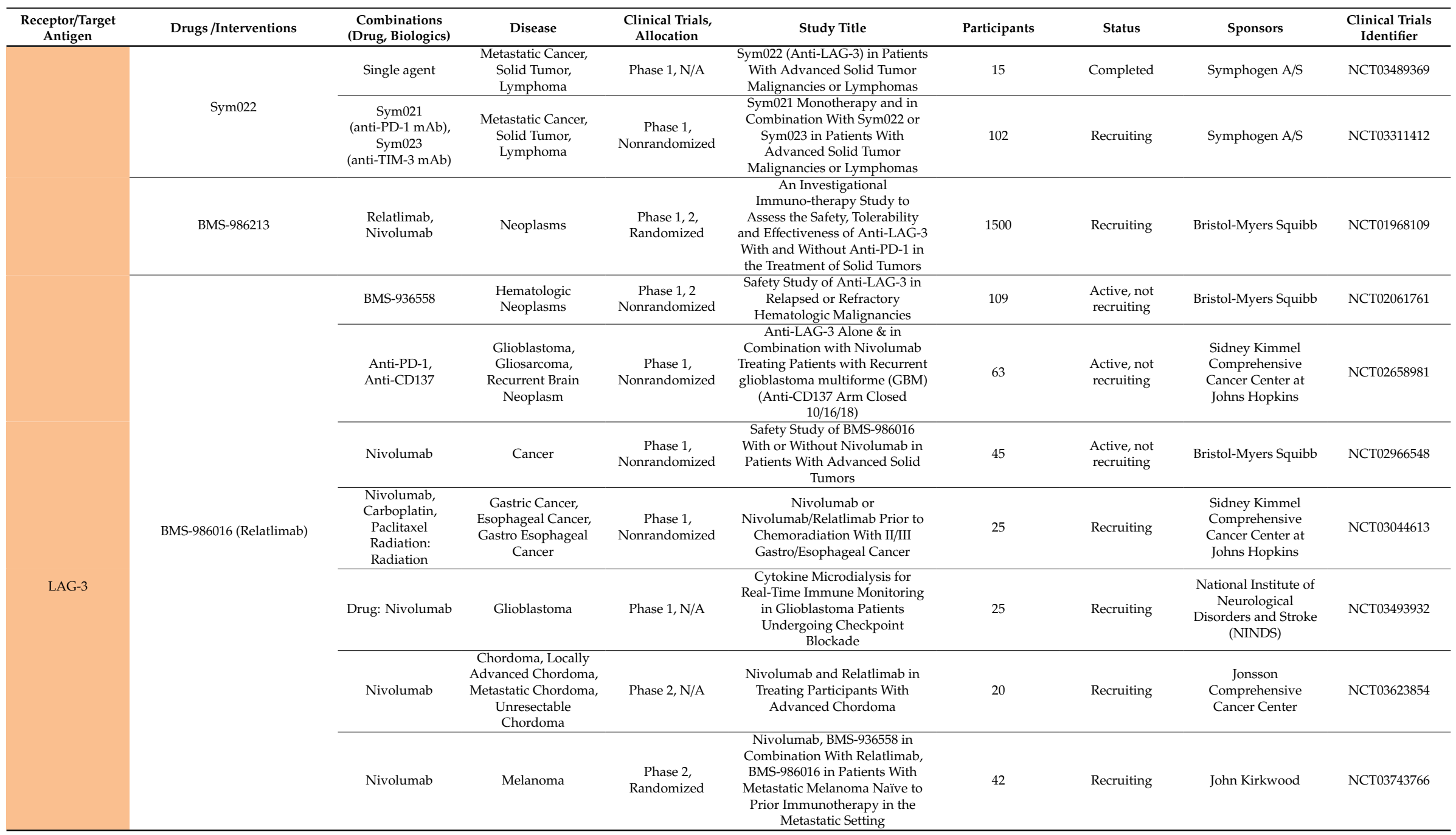


Table 1. Cont

\begin{tabular}{|c|c|c|c|c|c|c|c|c|c|}
\hline $\begin{array}{c}\text { Receptor/Target } \\
\text { Antigen }\end{array}$ & Drugs/Interventions & $\begin{array}{c}\text { Combinations } \\
\text { (Drug, Biologics) }\end{array}$ & Disease & $\begin{array}{l}\text { Clinical Trials, } \\
\text { Allocation }\end{array}$ & Study Title & Participants & Status & Sponsors & $\begin{array}{c}\text { Clinical Trials } \\
\text { Identifier }\end{array}$ \\
\hline & \multirow{4}{*}{ IMP321 (eftilagimod alpha) } & $\begin{array}{l}\text { Placebo, } \\
\text { Paclitaxel }\end{array}$ & $\begin{array}{l}\text { Adenocarcinoma } \\
\text { Breast Stage IV }\end{array}$ & $\begin{array}{c}\text { Phase 2, } \\
\text { Randomized }\end{array}$ & $\begin{array}{l}\text { IMP321 (Eftilagimod Alpha) as } \\
\text { Adjunctive to a Standard } \\
\text { Chemotherapy Paclitaxel } \\
\text { Metastatic Breast Carcinoma }\end{array}$ & 241 & $\begin{array}{l}\text { Active, not } \\
\text { recruiting }\end{array}$ & Immutep S.A. & NCT02614833 \\
\hline & & Pembrolizumab & $\begin{array}{l}\text { Stage III, IV } \\
\text { Melanoma }\end{array}$ & Phase 1 & $\begin{array}{c}\text { Phase } 1 \text { Study of IMP321 } \\
\text { (Eftilagimod Alpha) Adjuvant to } \\
\text { Anti-programmed cell death } \\
\text { protein }-1 \text { (PD-1) Therapy in } \\
\text { Unresectable or Metastatic } \\
\text { Melanoma }\end{array}$ & 24 & Completed & $\begin{array}{l}\text { Immutep Australia } \\
\text { Pty. Ltd. }\end{array}$ & NCT02676869 \\
\hline & & Avelumab & $\begin{array}{c}\text { Solid Tumors, } \\
\text { Peritoneal } \\
\text { Carcinomatosis } \\
\end{array}$ & $\begin{array}{c}\text { Phase 1, } \\
\text { Nonrandomized }\end{array}$ & $\begin{array}{c}\text { Feasibility and Safety of IMP321 } \\
\text { for Advanced Stage Solid } \\
\text { Tumors } \\
\end{array}$ & 26 & $\begin{array}{l}\text { Active, not } \\
\text { recruiting }\end{array}$ & $\begin{array}{l}\text { InstitutfürKlinischeKrebs } \\
\text { IKF GmbH at } \\
\text { KrakkenhausNordwest }\end{array}$ & $\begin{array}{l}\text { orschung } \\
\text { NCT03252938 }\end{array}$ \\
\hline & & Pembrolizumab & $\begin{array}{l}\text { Non-small-cell lung } \\
\text { carcinoma (NSCLC), } \\
\text { Head and Neck } \\
\text { squamous cell } \\
\text { carcinoma (HNSCC) }\end{array}$ & $\begin{array}{c}\text { Phase 2, } \\
\text { Nonrandomized }\end{array}$ & $\begin{array}{c}\text { Combination Study With Soluble } \\
\text { LAG-3 Fusion Protein } \\
\text { Eftilagimod Alpha (IMP321) and } \\
\text { Pembrolizumab in Patients With } \\
\text { Previously Untreated } \\
\text { Unresectable or Metastatic } \\
\text { NSCLC, or Recurrent PD-X } \\
\text { Refractory NSCLC or With } \\
\text { Recurrent or Metastatic HNSCC } \\
\text { (TACTI-002) }\end{array}$ & 109 & Recruiting & Immutep S.A. & NCT03625323 \\
\hline
\end{tabular}


Table 1. Cont

\begin{tabular}{|c|c|c|c|c|c|c|c|c|c|}
\hline $\begin{array}{c}\text { Receptor/Target } \\
\text { Antigen }\end{array}$ & Drugs /Interventions & $\begin{array}{c}\begin{array}{c}\text { Combinations } \\
\text { (Drug, Biologics) }\end{array} \\
\end{array}$ & Disease & $\begin{array}{c}\text { Clinical Trials, } \\
\text { Allocation } \\
\end{array}$ & Study Title & Participants & Status & Sponsors & $\begin{array}{c}\text { Clinical Trials } \\
\text { Identifier }\end{array}$ \\
\hline \multirow{9}{*}{ TIM-3 } & Sym023 (anti-TIM-3) & Single agent & $\begin{array}{l}\text { Metastatic Cancer } \\
\text { Solid Tumor } \\
\text { Lymphoma } \\
\end{array}$ & Phase 1, N/A & $\begin{array}{l}\text { Sym023 (Anti-TIM-3) in Patients } \\
\text { With Advanced Solid Tumor } \\
\text { Malignancies or Lymphomas } \\
\end{array}$ & 24 & $\begin{array}{l}\text { Active, not } \\
\text { recruiting }\end{array}$ & Symphogen A/S & NCT03489343 \\
\hline & \multirow{3}{*}{ Drug: TSR-022 (anti-TIM-3 mAb) } & $\begin{array}{l}\text { TSR-042 (an } \\
\text { anti-PD-1 } \\
\text { antibody), } \\
\text { TSR-033 (an } \\
\text { anti-LAG-3 } \\
\text { antibody) }\end{array}$ & $\begin{array}{l}\text { Advanced or } \\
\text { Metastatic Solid } \\
\text { Tumors }\end{array}$ & $\begin{array}{c}\text { Phase 1, } \\
\text { Nonrandomized }\end{array}$ & $\begin{array}{l}\text { A Phase } 1 \text { Study of TSR-022, an } \\
\text { Anti-TIM-3 Monoclonal } \\
\text { Antibody, in Patients With } \\
\text { Advanced Solid Tumors } \\
\text { (AMBER) }\end{array}$ & 873 & Recruiting & Tesaro, Inc. & NCT02817633 \\
\hline & & TSR-042 & $\begin{array}{l}\text { Adult Primary Liver } \\
\text { Cancer Advanced } \\
\text { Adult Primary Liver } \\
\text { Cancer Localized } \\
\text { Unresectable Adult } \\
\text { Primary Liver Cancer }\end{array}$ & Phase 2, N/A & $\begin{array}{l}\text { TSR-022 (Anti-TIM-3 Antibody) } \\
\text { and TSR-042 (Anti-PD-1 } \\
\text { Antibody) in Patients With Liver } \\
\text { Cancer }\end{array}$ & 42 & Recruiting & University of Hawaii & NCT03680508 \\
\hline & & $\begin{array}{c}\text { Dostarlimab } \\
\text { (TSR-042) (singly) }\end{array}$ & $\begin{array}{l}\text { Melanoma Stage III, } \\
\text { IV }\end{array}$ & $\begin{array}{c}\text { Phase 2, } \\
\text { Randomized }\end{array}$ & $\begin{array}{l}\text { Neoadjuvant PD-1 Inhibitor } \\
\text { Dostarlimab (TSR-042) vs. } \\
\text { Combination of Tim-3 Inhibitor } \\
\text { TSR-022 and PD-1 Inhibititor } \\
\text { Dostarlimab (TSR-042) in } \\
\text { Melanoma } \\
\end{array}$ & 56 & Recruiting & Diwakar Davar & NCT04139902 \\
\hline & LY3321367 (anti-TIM-3 mAb) & LY3300054 & Solid Tumor & $\begin{array}{c}\text { Phase 1, } \\
\text { Nonrandomized }\end{array}$ & $\begin{array}{c}\text { A Study of LY3321367 Alone or } \\
\text { With LY3300054 in Participants } \\
\text { With Advanced } \\
\text { Relapsed/Refractory Solid } \\
\text { Tumors } \\
\end{array}$ & 275 & $\begin{array}{l}\text { Active, not } \\
\text { recruiting }\end{array}$ & $\begin{array}{l}\text { Eli Lilly and } \\
\text { Company }\end{array}$ & NCT03099109 \\
\hline & BGB-A425 (anti-TIM-3 mAb) & Tislelizumab & $\begin{array}{l}\text { Locally Advanced or } \\
\text { Metastatic Solid } \\
\text { Tumors }\end{array}$ & $\begin{array}{c}\text { Phase 1,2, } \\
\text { Nonrandomized }\end{array}$ & $\begin{array}{l}\text { Study of BGB-A425 in } \\
\text { Combination With Tislelizumab } \\
\text { in Advanced Solid Tumors }\end{array}$ & 162 & Recruiting & BeiGene & NCT03744468 \\
\hline & \multirow{3}{*}{ MBG453 (anti-TIM-3 hmAb) } & $\begin{array}{l}\text { PDR001 } \\
\text { (anti-PD-1), } \\
\text { Decitabine }\end{array}$ & $\begin{array}{l}\text { Advanced } \\
\text { Malignancies }\end{array}$ & $\begin{array}{c}\text { Phase 1,2, } \\
\text { Nonrandomized }\end{array}$ & $\begin{array}{l}\text { Phase I-Ib/II Study of MBG453 as } \\
\text { Single Agent and in } \\
\text { Combination With PDR001 in } \\
\text { Patients With Advanced } \\
\text { Malignancies } \\
\end{array}$ & 269 & Recruiting & $\begin{array}{c}\text { Novartis } \\
\text { Pharmaceuticals }\end{array}$ & NCT02608268 \\
\hline & & $\begin{array}{l}\text { Decitabine, } \\
\text { PDR001 }\end{array}$ & $\begin{array}{l}\text { Leukemia, Myeloid } \\
\text { Leukemia, Acute } \\
\text { Myeloid Leukemia, } \\
\text { Myelodysplastic } \\
\text { Syndromes, } \\
\text { Preleukemia, Bone } \\
\text { Marrow Diseases, } \\
\text { Hematologic Diseases }\end{array}$ & $\begin{array}{c}\text { Phase 1, } \\
\text { Randomized }\end{array}$ & $\begin{array}{l}\text { Study of PDR001 and/or } \\
\text { MBG453 in Combination With } \\
\text { Decitabine in Patients With AML } \\
\text { or High Risk MDS }\end{array}$ & 235 & Recruiting & $\begin{array}{c}\text { Novartis } \\
\text { Pharmaceuticals }\end{array}$ & NCT03066648 \\
\hline & & $\begin{array}{l}\text { Spartalizumab } \\
\text { (PDR001) }\end{array}$ & $\begin{array}{l}\text { Glioblastoma, } \\
\text { Multiforme }\end{array}$ & Phase 1, N/A & $\begin{array}{l}\text { Trial of Anti-Tim-3 in } \\
\text { Combination With Anti-PD-1 } \\
\text { and Stereotactic radiosurgery } \\
\text { (SRS) in Recurrent GBM }\end{array}$ & 15 & $\begin{array}{l}\text { Active, not } \\
\text { recruiting }\end{array}$ & $\begin{array}{l}\text { Sidney Kimmel } \\
\text { Comprehensive } \\
\text { Cancer Center at } \\
\text { Johns Hopkins }\end{array}$ & NCT03961971 \\
\hline
\end{tabular}


Table 1. Cont

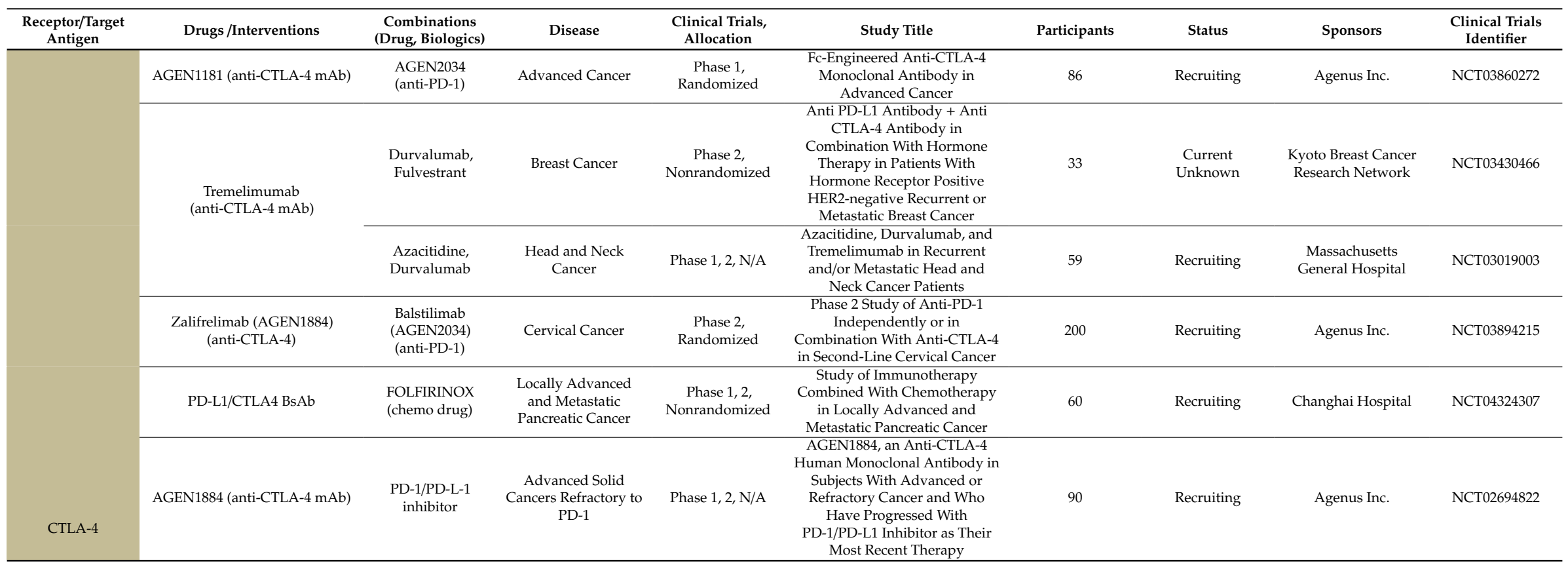


Table 1. Cont

\begin{tabular}{|c|c|c|c|c|c|c|c|c|c|}
\hline $\begin{array}{c}\text { Receptor/Target } \\
\text { Antigen }\end{array}$ & Drugs /Interventions & $\begin{array}{c}\text { Combinations } \\
\text { (Drug, Biologics) }\end{array}$ & Disease & $\begin{array}{l}\text { Clinical Trials, } \\
\text { Allocation }\end{array}$ & Study Title & Participants & Status & Sponsors & $\begin{array}{c}\text { Clinical Trials } \\
\text { Identifier }\end{array}$ \\
\hline & \multirow{4}{*}{$\begin{array}{c}\text { Ipilimumab (MDX-010) } \\
\text { (BMS-734016) } \\
\text { (anti-CTLA-4 mAb) }\end{array}$} & Docetaxel & Prostate Cancer & $\begin{array}{l}\text { Phase 2, } \\
\text { Randomized }\end{array}$ & $\begin{array}{l}\text { Comparison Study of MDX-010 } \\
\text { (CTLA-4) Alone and Combined } \\
\text { With Docetaxel in the Treatment } \\
\text { of Patients With Hormone } \\
\text { Refractory Prostate Cancer }\end{array}$ & N/A & Completed & Bristol-Myers Squibb & NCT00050596 \\
\hline & & Single agent & Melanoma & $\begin{array}{l}\text { Phase 2, } \\
\text { Randomized }\end{array}$ & $\begin{array}{l}\text { Study of Ipilimumab (MDX-010) } \\
\text { Monotherapy in Patients With } \\
\text { Previously Treated Unresectable } \\
\text { Stage III or IV Melanoma }\end{array}$ & 210 & Completed & Bristol-Myers Squibb & NCT00289640 \\
\hline & & $\begin{array}{l}\text { REGN2810, } \\
\text { Pembrolizumab }\end{array}$ & $\begin{array}{l}\text { Non-small Cell Lung } \\
\text { Cancer }\end{array}$ & $\begin{array}{c}\text { Phase } 3, \\
\text { Randomized }\end{array}$ & $\begin{array}{c}\text { REGN2810 (Anti-PD-1 } \\
\text { Antibody), Platinum-based } \\
\text { Doublet Chemotherapy, and } \\
\text { Ipilimumab (Anti-CTLA-4 } \\
\text { Antibody) Versus } \\
\text { Pembrolizumab Monotherapy in } \\
\text { Patients With Lung Cancer }\end{array}$ & 5 & $\begin{array}{l}\text { Active, not } \\
\text { recruiting }\end{array}$ & $\begin{array}{l}\text { Regeneron } \\
\text { Pharmaceuticals }\end{array}$ & NCT03515629 \\
\hline & & SHR-1210 & $\begin{array}{l}\text { Non-small Cell Lung } \\
\text { Cancer }\end{array}$ & Phase 1, N/A & $\begin{array}{l}\text { Anti-CTLA-4 Antibody } \\
\text { Followed by Anti-PD-1 } \\
\text { Antibody in Recurrent or } \\
\text { Metastatic NSCLC (SEQUENCE) }\end{array}$ & 10 & $\begin{array}{l}\text { Current } \\
\text { Unknown }\end{array}$ & $\begin{array}{l}\text { Sun Yat-sen } \\
\text { University }\end{array}$ & NCT03527251 \\
\hline & $\begin{array}{l}\text { AK104, a PD-1 and CTLA-4 } \\
\text { bispecific antibody }\end{array}$ & Single agent & $\begin{array}{l}\text { Advanced solid } \\
\text { tumor }\end{array}$ & Phase 1, 2, N/A & $\begin{array}{l}\text { Safety and Efficacy of AK104, a } \\
\text { PD-1/CTLA-4 Bispecific } \\
\text { Antibody, in Selected Advanced } \\
\text { Solid Tumors } \\
\end{array}$ & 120 & Not yet recruiting & Akeso & NCT04172454 \\
\hline & Tremelimumab & Olaparib & $\begin{array}{l}\text { Ovarian Cancer } \\
\text { Fallopian Tube } \\
\text { Cancer Peritoneal } \\
\text { Neoplasms }\end{array}$ & Phase 1, 2, N/A & $\begin{array}{c}\text { PARP-inhibition and CTLA-4 } \\
\text { Blockade in BRCA-deficient } \\
\text { Ovarian Cancer }\end{array}$ & 50 & Recruiting & $\begin{array}{l}\text { New Mexico Cancer } \\
\text { Care Alliance }\end{array}$ & NCT02571725 \\
\hline & $\begin{array}{c}\text { MGD019 (DART protein binding } \\
\text { PD-1 and CTLA-4) }\end{array}$ & Single agent & $\begin{array}{l}\text { Solid Tumor, Adult } \\
\text { Advanced Cancer }\end{array}$ & Phase 1, N/A & $\begin{array}{c}\text { MGD019 DART Protein in } \\
\text { Unresectable/Metastatic Cancer }\end{array}$ & & Recruiting & MacroGenics & NCT03761017 \\
\hline & CS1002 (anti-CTLA-4 mAb) & $\begin{array}{l}\text { CS1003 (anti-PD-1 } \\
\text { mAb) }\end{array}$ & Solid tumor, Adult & $\begin{array}{c}\text { Phase 1, } \\
\text { Randomized }\end{array}$ & $\begin{array}{l}\text { A Study of CS1002 in Subjects } \\
\text { With Advanced Solid Tumors }\end{array}$ & 108 & Recruiting & $\begin{array}{c}\text { CStone } \\
\text { Pharmaceuticals }\end{array}$ & NCT03523819 \\
\hline
\end{tabular}


Table 1. Cont.

\begin{tabular}{|c|c|c|c|c|c|c|c|c|c|}
\hline $\begin{array}{l}\text { Receptor/Target } \\
\text { Antigen }\end{array}$ & Drugs /Interventions & $\begin{array}{c}\text { Combinations } \\
\text { (Drug, Biologics) }\end{array}$ & Disease & $\begin{array}{l}\text { Clinical Trials, } \\
\text { Allocation }\end{array}$ & Study Title & Participants & Status & Sponsors & $\begin{array}{l}\text { Clinical Trials } \\
\text { Identifier }\end{array}$ \\
\hline \multirow{12}{*}{ PD-1 } & \multirow[b]{2}{*}{$\begin{array}{c}\text { Pembrolizumab (MK-3475) } \\
\text { (lambrolizumab) }\end{array}$} & Single agent & Anal Cancer & Phase 2, N/A & $\begin{array}{l}\text { Pembrolizumab in Refractory } \\
\text { Metastatic Anal Cancer }\end{array}$ & 32 & Recruiting & $\begin{array}{l}\text { Dana-Farber Cancer } \\
\text { Institute }\end{array}$ & NCT02919969 \\
\hline & & $\begin{array}{l}\text { Radiation: RT } \\
\text { Boost }\end{array}$ & Breast Cancer & Phase 1, 2, N/A & $\begin{array}{c}\text { Breast Cancer Study of } \\
\text { Preoperative Pembrolizumab + } \\
\text { Radiation }\end{array}$ & 60 & Recruiting & Stephen Shiao & NCT03366844 \\
\hline & \multirow[b]{2}{*}{$\begin{array}{l}\text { Nivolumab (anti-PD-1 mAb) } \\
\text { (Opdivo) }\end{array}$} & Single agent & Prostate Cancer & $\begin{array}{c}\text { Phase 2, } \\
\text { Nonrandomized }\end{array}$ & $\begin{array}{l}\text { Nivolumab in Patients With } \\
\text { High-Risk Biochemically } \\
\text { Recurrent Prostate Cancer }\end{array}$ & 34 & Recruiting & $\begin{array}{l}\text { Beth Israel Deaconess } \\
\text { Medical Center }\end{array}$ & NCT03637543 \\
\hline & & DKN-01 & Biliary tract cancer & $\begin{array}{c}\text { Phase 2, } \\
\text { Nonrandomized }\end{array}$ & $\begin{array}{l}\text { Study of the Combination of } \\
\text { DKN-01 and Nivolumab in } \\
\text { Previously Treated Patients With } \\
\text { Advanced Biliary Tract Cancer } \\
\text { (BTC) }\end{array}$ & 30 & Recruiting & $\begin{array}{l}\text { Massachusetts } \\
\text { General Hospital }\end{array}$ & NCT04057365 \\
\hline & \multirow[b]{2}{*}{$\begin{array}{l}\text { Atezolizumab (anti-PD-1 mAb) } \\
\text { (MPDL3280A) (RG7446) }\end{array}$} & Single agent & $\begin{array}{l}\text { Non-small Cell Lung } \\
\text { Cancer }\end{array}$ & Phase 2, N/A & $\begin{array}{c}\text { Atezolizumab in Advanced } \\
\text { Non-small Cell Lung Cancer } \\
\text { With Rare Histologies (CHANCE } \\
\text { Trial) (CHANCE) }\end{array}$ & 43 & Recruiting & $\begin{array}{l}\text { GruppoOncologicoItalian } \\
\text { di RicercaClinica }\end{array}$ & ${ }^{10} \mathrm{NCT} 03976518$ \\
\hline & & Single agent & Breast Cancer & Phase 2, N/A & $\begin{array}{l}\text { A Study of Atezolizumab in } \\
\text { Participants With Locally } \\
\text { Advanced or Metastatic } \\
\text { Urothelial Bladder Cancer } \\
\text { (Cohort 1) }\end{array}$ & 119 & $\begin{array}{l}\text { Active, not } \\
\text { recruiting }\end{array}$ & Hoffmann-La Roche & NCT02951767 \\
\hline & \multirow[t]{2}{*}{ Avelumab (MSB0010718C) } & Single agent & $\begin{array}{l}\text { Metastatic Colorectal } \\
\text { Cancer }\end{array}$ & Phase 2, N/A & $\begin{array}{l}\text { Avelumab for microsatellite } \\
\text { instability-high (MSI-H) or } \\
\text { POLE (i.e. Mutations in the } \\
\text { exonuclease domain of the DNA } \\
\text { polymerase epsilon (POLE) gene) } \\
\text { Mutated Metastatic Colorectal } \\
\text { Cancer }\end{array}$ & 33 & $\begin{array}{l}\text { Active, not } \\
\text { recruiting }\end{array}$ & Asan Medical Center & NCT03150706 \\
\hline & & Axitinib & Cervical Cancer & Not applicable & $\begin{array}{l}\text { Avelumab With Axitinib in } \\
\text { Persistent or Recurrent Cervical } \\
\text { Cancer After Platinum-based } \\
\text { Chemotherapy (ALARICE) }\end{array}$ & 23 & Recruiting & $\begin{array}{l}\text { The University of } \\
\text { Hong Kong }\end{array}$ & NCT03826589 \\
\hline & \multirow[b]{2}{*}{ Durvalumab (MEDI4736) } & Single agent & Bladder Cancer & Phase 2, N/A & $\begin{array}{l}\text { Efficacy of Durvalumab in } \\
\text { Non-muscle-invasive } \\
\text { Bladder Cancer }\end{array}$ & 39 & Recruiting & $\begin{array}{l}\text { Hellenic Genito } \\
\text { Urinary Cancer } \\
\text { Group }\end{array}$ & NCT03759496 \\
\hline & & $\begin{array}{l}\text { Azacitidine, } \\
\text { Tremelimumab }\end{array}$ & $\begin{array}{l}\text { Head and Neck } \\
\text { Cancer }\end{array}$ & Phase 1, 2, N/A & $\begin{array}{l}\text { Azacitidine, Durvalumab, and } \\
\text { Tremelimumab in Recurrent } \\
\text { and/or Metastatic Head and } \\
\text { Neck Cancer Patients }\end{array}$ & 59 & Recruiting & $\begin{array}{l}\text { Massachusetts } \\
\text { General Hospital }\end{array}$ & NCT03019003 \\
\hline & \multirow[b]{2}{*}{$\begin{array}{l}\text { Cemiplimab (REGN-2810) } \\
\text { (Libtayo) }\end{array}$} & Plerixafor & $\begin{array}{l}\text { Metastatic Pancreatic } \\
\text { Cancer }\end{array}$ & Phase 2, N/A & $\begin{array}{l}\text { Plerixafor and Cemiplimab in } \\
\text { Metastatic Pancreatic Cancer }\end{array}$ & 21 & Not yet recruiting & $\begin{array}{l}\text { Sidney Kimmel } \\
\text { Comprehensive } \\
\text { Cancer Center at } \\
\text { Johns Hopkins } \\
\end{array}$ & NCT04177810 \\
\hline & & REGN5678 & $\begin{array}{c}\text { Metastatic } \\
\text { Castration-resistant } \\
\text { Prostate Cancer }\end{array}$ & $\begin{array}{c}\text { Phase 1, 2, } \\
\text { Nonrandomized }\end{array}$ & $\begin{array}{c}\text { Study of REGN5678 } \\
\text { (Anti-PSMAxCD28) With } \\
\text { Cemiplimab (Anti-PD-1) in } \\
\text { Patients With Metastatic } \\
\text { Castration-resistant } \\
\text { Prostate Cancer }\end{array}$ & 123 & Recruiting & $\begin{array}{l}\text { Regeneron } \\
\text { Pharmaceuticals }\end{array}$ & NCT03972657 \\
\hline
\end{tabular}


Another immune checkpoint costimulatory molecule, OX40 (also known as TNFRSF4 or CD134), is a transmembrane glycoprotein and a member of the tumor necrosis factor (TNF) receptor superfamily $[82,83]$. CD134 is recognized as a costimulatory receptor, is transiently expressed by $\mathrm{T}$ cells, and is essential for regulating T cell differentiation and survival [84]. The ligand for OX40 (OX40L or CD252) belongs to the TNF superfamily and is mainly expressed by APCs such as dendritic cells, macrophages, and activated B cells, as well as T cells [85-87]. Among other checkpoint costimulatory molecules, OX40 is a promising therapeutic modality for inflammatory and autoimmune diseases, as it can induce antitumor immunity through effector T cell and NK cells. Preliminary studies have shown that OX40-OX40L interaction between T cells and APCs modulates T cell function [88-90] and is decisive for the generation of memory T cells [91,92]. Besides, the combination of cytokines IL-2, IL-15, and IL-18 can induce OX40L expression on NK cells following stimulation through activating receptors using anti-CD16 or anti-NKG2Dantibodies. Further, activated NK cells costimulate autologous CD4+ $\mathrm{T}$ cell proliferation and IFN- $\gamma$ production via OX40-OX40L interaction [93]. This cross-talk of human $\mathrm{NK}$ cells and $\mathrm{T}$ cells demonstrates its role as a molecule relevant for linking innate and adaptive immune cells.

In contrast to the wealth of data on $\mathrm{T}$ cells, the characteristics of OX40/OX40L in NK cells are poorly understood. The most recent data showed low-level expression of CD134 receptor in NK cells [94]. In a preclinical study on mice bearing established subcutaneous B16 melanoma, the interaction of CD134 on NK cells with CD134L present on dendritic cells resulted in the release of IFN- $\gamma$ and induced T cell cross-priming against multiple tumor antigens [95]. In another preclinical study, human NK cells showed transiently upregulated CD134 in coculture with Rituximab-opsonized Ramos B cell lymphoma cells, and after stimulation with agonistic anti-CD134 mAb, demonstrated enhanced cytotoxicity and cytokine release in human NK cells [96]. Gene expression profiling of NK cells showed a 4-fold increases in 4-1BBL expression upon activation of NK cells [97]. Regarding other checkpoint costimulatory molecules, OX40 is the furthest along in clinical development. Despite the obscure role of OX40 in NK cells, OX40-targeting drugs utilized in initial trials and preliminary data showed satisfactory result and signs of clinical activity. In a phase 1 clinical trial, 9B12 (an OX40-targeting agent) showed good tolerance and moderate toxicity in patients with solid metastatic malignancies [98]. Currently, the outcome from a clinical trial is its safety using OX40/OX40L-targeted therapy, which indicates the requirement of further exploration. In a translation research study, a murine anti-OX40 antibody (9B12) directed against the extracellular domains of human OX40 (CD134) was tested in a phase I clinical trial, and was found to be well-tolerated and to promote both humoral and cellular immunity in patients with cancer [98]. Later, humanized monoclonal antibodies against OX40 (GSK3174998) was developed by GlaxoSmithKline PLC, Brontford (United Kingdom) in partnership with Merck \& Co., New Jersey (United States) designed to bind to OX40 on activated T cells, and is currently under investigation for use alone or in combination with Pembrolizumab (anti-neoplastic agents) in advanced solid tumor patients (NCT02528357) (Table 1).

Another modulator, GITR (glucocorticoid-induced TNFR family-related gene), a member of the TNFR superfamily (TNFRSF), was initially cloned in a glucocorticoid-treated hybridoma T cell line [99]. It has high similarity in its cytoplasmic region toother TNFRSF members [100], namely 4-1BB, CD27, OX40, and CD40, which all employ costimulatory activity [101,102]. Preliminary studies showed that Tregs express GITR and engagement with the soluble form of GITR ligand, thus abrogating the suppressive function of Tregs [103]. Later, studies also confirmed its presence on helper and cytotoxic T cells [104], macrophages, and NK cells [56,105], whereas the cognate ligand (GITRL) is expressed on antigen-presenting cells, such as dendritic cells [106]. In the case of NK cells, there is constitutively low expression of GITR, but is upregulated upon activation by both toll-like receptors (TLRs) ligand and NK cell growth factor, IL-15 [107], and binds to its respective ligand, GITRL (a type II transmembrane protein) [108]. Upon interaction, the TNFR ligand is expressed in antigen-presenting cells and forms trimers for crosslinking the receptors. Similar to OX40, GITR modulates immune cell activation through costimulation and increases the proliferation, activation, and cytokine production of cytotoxic 
T cells, but its role in NK cells remains controversial [109]. Hanabuchi et al. [110] demonstrated that GITR-GITRL interactions enhanced both NK cell cytotoxic activity and IFN- $\gamma$ production in NK cells. However, another study reported that GITRL-positive tumor cells downregulate NK cell cytotoxicity and inhibits IFN- $\gamma$ release [56]. Later, GITR signalling mechanisms were investigated, and it was concluded that GITR serves as a negative regulator of NK cell activation by enhancing NK cell apoptosis [107]. Conclusively, the interactions between NK cells with GITRL-expressing cells and the presence of reverse signalling indicate the homeostasis of NK cells during inflammation, which provides strong evidence for a much broader role than initially recognized. Moreover, its antitumor activity and expression in activated NK cells should be studied further. Initially, agonistic GITR antibodies can attenuate the suppressive function of Tregs, as well as stimulate effector T cells to overcome Tregs-mediated suppression, which makes it a promising target for clinical development [111-113]. Based on the preclinical activity of the agonist anti-GITR antibodies, Merghoub et al [114] investigated the first human phase 1 trial of GITR agonism with the anti-GITR antibody TRX518 (NCT01239134). TRX518, a humanized Fc-dysfunctional aglycosylated anti-human GITR mAb, induces GITR signalling. The phase I clinical trial showed preliminary affirmative response from the patients due to depletion of GITR-positive Tregs [114].

Thus, we postulate that NK cells mediate a protection mechanism against various stressed cells due to upregulation of the cellular stress response, which triggers the stress-induced ligand and activates the effector cells. Thus, formulating a NK cell-based immunotherapy that can concurrently engage these cellular stress responses along with immune checkpoint costimulator-based therapy will lead to a more active, targeted, and safe approach of therapeutic development. Immune checkpoint costimulators such as OX40, CD137, and GITR are expressed mostly following stimulation the lymphocytes, which makes them safe to target with agonistic antibodies [115].

\subsection{Immune Checkpoint Inhibitors}

The dysfunctional status of NK cells can link to exhaustion, anergy, and senescence. Immune checkpoint inhibitors, such as $\mathrm{T}$ cell immunoglobulin and immunoreceptor tyrosine-based inhibitory motif domains (TIGIT) and CD96, represents a type I transmembrane glycoprotein belonging to the immunoglobulin superfamily [116,117], cytotoxic T-lymphocyte-associated protein 4 (CTLA-4) [118], KIRs [34], lymphocyte-activation gene-3 (LAG-3) [119], PD-1 [120], T cell immunoglobulin and mucin-domain containing-3 (TIM-3) [121], and sialic acid-binding immunoglobulin-type lectins (SIGLECs) [122] have shown remarkable efficiency in the development of immunotherapy (Figure 3B). However, knowledge of the expression of various immune checkpoints in NK cells and dissecting the role of these inhibitory mechanisms in NK cells is essential for the full interpretation of the mode of action of immune-checkpoint-based therapy in the treatment of cancers.

NK cells prevent healthy cell targeting through MHC-I specific inhibitory receptors, such as KIRs and CD94-NKG2A, through the immunoreceptor tyrosine-based inhibition motif (ITIM), which recognizes the human leukocyte antigen-E (HLA-E) ligand on healthy cells and suppress signalling activation [123]. However, tumor cells induce expression of the non-classical MHC class I molecule, the HLA-E ligand, in order to escape from NK cell-mediated action [124]. NKG2 lectin-like receptor (also known as CD159) is expressed as a heterodimer with CD94 on NK cells and specifically recognizes HLA-E. It has been reported that HLA-E is an effective suppressive factor, and its expression on tumor cells negatively correlates with patients' overall survival $[125,126]$. Upon engagement to its cognate ligand, CD94/NKG2A delivers inhibitory signals [127-129]. Tumor-infiltrating NK cells express a high level of NKG2A, and the frequency of NKG2A+NK cells correlates with the secretion of IL-15 and TGF- $\beta$ in solid tumor [130-132]. The blocking of NKG2A-HLA-E binding greatly enhances antitumor properties of tumor-infiltrating NK cells as confirmed both in vitro and in vivo $[133,134]$. In vitro and in vivo studies have shown the application of humanized anti-NKG2A antibodies against malignancies to be safe and effective [134,135]. It is wise to block the CD94/NKG2A receptor in order to avoid immune escape as a therapeutic strategy. Hence, a blocking antibody 
against CD94/NKG2A (IPH2201-Monalizumab) developed by Innate Pharma, Marseille (France) is currently under trial in phase I/II clinical trials as a monotherapy (NCT02459301) [136]. Several studies have reported that PD-1 is coexpressed along with NKG2A in tumor-infiltrating NK cells; therefore, a combination of Monalizumab and Durvalumab is currently under trial and has shown clinical efficacy [132]. Preliminary results have determined that combined blocking of the NKG2A/HLA-E and PD-1/PD-L1 pathways with blocking antibodies has promising efficacy $[132,137]$. Furthermore, combination of Monalizumab with other compounds such as the anti-EGFR mAb (Cetuximab) in patients with recurrent or metastatic solid tumor (NCT02643550) and inhibitor of Bruton tyrosine kinase (ibrutinib) in relapsed/refractory CLL (NCT02557516) are also under investigation. Overall, NKG2A blockade shows a promising therapeutic approach, and its combination with other checkpoint molecules is the way forward and requires further exploration.

The KIRs (also known as CD158) are polymorphic receptors that recognize a specific HLA class I allotype (HLA-A, -B, or -C) as a cognate ligand [138]. Upon interaction with their associated ligands, KIRs execute an inhibitory signal that prevents NK cell activation towards MHC-I positive, healthy autologous cells [139-141]. There are a total of 17 KIR genes with diverse allelic combinations [142-144]. The clinical relevance of KIR inhibition has been reported in allogeneic haploidentical stem cell transplantation (HSCT) in AML patients from KIR ligand-mismatched donors. Activation of NK cells and eradication of residual leukaemia was reported [145-147]. In a clinical setting, infusion of KIR ligand-mismatched allogenic NK cells to advanced multiple myeloma patients, followed by HSCT, showed promising results along with no graft-versus-host disease [148]. Accumulating evidence indicates the benefits of pharmacological exploitation of combining KIR blockade therapy with another immunotherapy. For instance, the blockade of KIR releases the inhibition breaks and assist in Rituximab-dependent NK cell-mediated ADCC [149]. Alternatively, a combination of anti-KIR antibody (IPH 2101) and an immunomodulatory drug, i.e., Lenalidomide, in relapsed/refractory multiple myeloma patients, could be of interest in treatment [150]. Moreover, Lirilumab (IPH2102), a human IgG4 monoclonal antibody (mAb), has been evaluated for safety in various cancer patients, and a phase 1 trial confirmed its safety and blockade of KIR [151]. Furthermore, Lacutamab (also termed as IPH4102), a first-in-class humanized monoclonal antibody targeting KIR3DL2, has also been under evaluation in clinical trials, and was confirmed as a safe therapy against $\mathrm{T}$ cell lymphoma [152]. In clinical trials, there are limited side effects of KIR blockade alone, with slight efficacy [153]. However, the combination of PD-1 and KIR blockade, or CTLA-4 and KIR blockade, has shown increased response in chemotreated advanced head and neck cancer patients (NCT01714739). Both Lirilumab and Monalizumab (anti-NKG2A) are currently undergoing phase I/II clinical trials as monotherapies or in combination across a series of hematologic and solid cancers (Clinical trial.gov: Lirilumab: NCT02399917, NCT02599649, NCT02252263, NCT02481297, NCT01687387, NCT01714739, NCT01592370, NCT01750580; Monalizumab: NCT02921685, NCT02643550) (Table 1). The results of various clinical trials have reported that treatment with the anti-KIR antibody can induce an antitumor immune response in cancer patients [154].

TIGIT and CD96 are inhibitory checkpoint molecules from the same immunoglobulin superfamily, and are expressed on NK and T cells [116,155]. CD96 has lower binding affinity for the ligand CD155 compared to TIGIT, whereas DNAM-1 (CD226), an activating receptor, also competes with TIGIT and CD96 in binding to CD155 [156-158]. CD155 is a transmembrane glycoprotein, also known as PVR, that is highly expressed in many tumor cell lines and primary malignancies $[159,160]$. Various cancers have shown upregulation of CD155, which may bind to TIGIT and CD96 in order to evade NK cell-mediated antitumor immunity by eliciting NK cell inhibition, including suppression of granule polarization and IFN- $\gamma$ production [161-164]. TIGIT was shown to compete for binding to its cognate ligand with higher affinity than DNAM-1 [164] and downmodulates the NK cell-effector function, whereas CD96 dampens IFN- $\gamma$ production [158], which can be reversed by the disruption of interactions of TIGIT with its ligands [164]. Preclinical studies support the idea of blockading TIGIT/CD96 checkpoints to activate further NK cell-mediated antitumor immunity [157]. Patients 
with higher TIGIT expression in the bone marrow (BM) experience a graft-vs.-leukemia (GVL) effect and GVHD after HSCT in AML patients to control NK cell activation and proliferation. These observations conclude that TIGIT could be a prognostic predictor following HSCT and can be targeted as a potent immunotherapeutic modality in AML patients [165]. Recently, increased emphasis has placed on the combination of checkpoint inhibitors in order to produce higher efficacy. Since TIGIT acts synergistically with both TIM-3 and PD-1 to weaken the antitumor immune responses [166], a phase I trial has been evaluating a human anti-TIGIT mAb (MTIG7192A, RG6058) in combination with anti-PD-1 therapy in various solid tumors (NCT03563716). On the other hand, the preclinical study showed that CD96 mediates immune response, and blocking of CD96 promotes the release of IFN- $\gamma$ and an enhanced antitumor response [167]. In a clinical trial, a pharmaceutical cocktail containing anti-TIGIT (Etigilimab) and an anti-PD-1 (Nivolumab) antibody was used to eradicate cancer and restore immune response, and the results of this trial showed the tolerability of therapy [168]. Besides, a phase III trial (named as SKYSCRAPER-01) has been started recently by Hoffmann-La Roche, Basel (Switzerland) to evaluate the efficacy and safety of Tiragolumab (anti-TIGIT, RG6058), a fully human monoclonal antibody plus Atezolizumab (anti-PD-L1), compared with placebo plus Atezolizumab, i.e., an engineered monoclonal antibody of IgG1 isotype against the protein programmed cell death-ligand 1, in participants (NCT04294810).

Apart from these, all mammalian structures express distinct glycan structure, and Siglecs is one of them. Siglecs are immunomodulatory receptors belonging to the I-type lectin family [169]. Similar to NKG2A/CD94 and KIRs, human NK cells express inhibitory receptors, such as Siglec-7 and Siglec-9, which contain ITIM-like motifs in their cytoplasmic tail $[170,171]$ and are known to mediate both inhibitory and apoptotic signal [172]. The hypersialylation of membrane-bound glycans and proteins is considered a hallmark of cancer, which results in the covering of malignant cells with sialic-acid-derived ligands for inhibitory Siglec receptors, and has been shown to play a significant role in immune evasion and metastasis $[173,174]$. Desialylation of tumor cells is an excellent fundamental idea to determine whether Siglec receptor-ligand interactions may facilitate immune evasion. Accordingly, targeting Siglecs and modulating hypersialylation have come into the limelight as potential immunotherapeutic strategies. Currently, anti-Siglec-7 and Siglec-9-blocking antibodies promote NK cell-mediated cytotoxicity against a K562 malignant cell line [171]. Malignant cells express Siglec-7 ligands to escape from the innate immune response, as well as NK cell-mediated ADCC. In vitro infusion of sialidase cuts off the sialic acid ligands and enhances HER2 positive tumor cell killing by NK cells. This result showed that desialylation of tumors make them more prone to NK cell-mediated cytotoxicity $[175,176]$. However, a combination of NKG2A blockade and anti-Siglec antibodies showed improved antitumor response as compared to a single treatment. These data indicate the possibility that anti-Siglec-7 and anti-Siglec-9 blocking antibodies can be a promising therapeutic option along with other immune checkpoint inhibitors.

In 1990, Triebel and colleagues identified a novel human Ig superfamily, known as LAG-3, that is expressed on the cell surface of activated T and NK cells and is structurally similar to the CD4 receptor [177,178]. The LAG-3 receptor is expressed on other immune cell surfaces, including human tumor-infiltrating lymphocytes (TILs), Tregs, B cells, and DCs [179-182]. Usually, LAG-3 is undetectable in resting NK cells, where as it is upregulated in activated NK cells [177]. LAG-3 binds MHC-II, which is mainly expressed by APCs and malignant cells. LAG-3 also interacts with Human LSECtin (liver and lymph node sinusoidal endothelial cell C-type lectin, CLEC4G), which is widely expressed on many tumor cell surfaces [183]. The interaction of LAG-3 prevents the cytotoxic function of effector T cells and is responsible for T cell exhaustion [184-186]. Wherry et al. [187] have reported the coexpression of LAG-3 and PD-1 inhibitory receptors, which are involved in cytotoxic $\mathrm{T}$ cell exhaustion in response to viral infection, and dual blockade of these inhibitory receptors has demonstrated synergistic effects. However, additional experimental evidence suggests that LAG-3 may also play a key role in NK cell function. However, human NK cells did not show any similar results, and blocking LAG-3 did not provoke NK cell cytotoxicity [188,189]. Furthermore, a soluble recombinant 
LAG-3-Ig fusion protein, i.e., IMP321, has been studied as an immunological adjuvant for vaccination against cancer, and it was able to promote cytokine production of NK cells in a healthy individual and cancer patients in ex vivo culture conditions [190]. Relatlimab (an anti-LAG-3 mAbs), investigated either alone or in combination with PD-1 blocking antibody, has shown promising results [191,192]. Several clinical trials (NCT02658981; NCT03489369; NCT02061761; NCT01968109; NCT03005782) (Table 1) are focusing on determining the safety and efficacy of LAG-3 targeted treatment of a wide range of cancers. Hence, LAG-3 has the potential to activate NK cells, but the underlying mechanisms need further investigation.

TIM-3 is another coinhibitory receptor. It has four ligands, including galectin-9, HMGB1 (high mobility group protein B1 protein), CEACAM-1 (carcinoembryonic antigen cell adhesion molecule 1), and PtdSer (phosphatidylserine), in various malignant cells [121,155]. TIM-3, also known as hepatitis A virus cellular receptor 2, (HAVCR2) provides negative regulation to many lymphocytes [193]. The expression of TIM- 3 is diverse, including distinct immune cells such as $\mathrm{CD} 4^{+} \mathrm{T}$ cells, $\mathrm{CD} 8^{+} \mathrm{T}$ cells, and Tregs, [194,195]. TIM-3 expression on NK cells has several aspects to it. In NK cells, TIM-3 is expressed at a low level, but a variety of unique and overlapping stimuli, including several cytokines (IL-12, IL-15, and IL-18), induce TIM-3 expression [196,197], which is considered as a marker of NK cell exhaustion [198]. The exhausted peripheral NK cells upregulate TIM-3 expression in various cancers including gastric cancers [199], lung adenocarcinoma [200], and advanced melanoma [201]. TIM-3 binding to its cognate receptors results in exhaustion of NK cells, making it a negative regulator of NK cells, but its blockade has been shown to reverse NK cell dysfunction [190,198,202]. In order to restore the NK cell activity, several antibodies for TIM-3, such as Sym023, Cobolimab, LY3321367, BGB-A425, and MBG453, in combination with several anti-PD-1/PD-L1 antibodies, are under clinical trial against various cancers [203]. Thus, targeting TIM-3 has emerged as a promising approach for checkpoint-based immunotherapy development.

CTLA-4, a coinhibitory receptor, is expressed on activated human and murine NK cells, and activates T cells and inhibits their IFN- $\gamma$ release upon the engagement of its ligand B7-1, which is primarily expressed by APCs [204-206]. In a recent study, CD45 ${ }^{+} \mathrm{CD} 56^{+}$human NK cells isolated from healthy donors (HD), cultured with IL-2, IL-12, and IL-18 in combination, showed synergistic high expression of the CTLA- 4 receptor. IL-2 also promotes degranulation and IFN- $\gamma$ production in HD [204]. This new result may indicate a relationship between CTLA-4 haploinsufficient NK cells with high susceptibility to viral infections in affected patients and heterozygous germline mutations in CTLA-4 [207-209]. Similarly, in vitro studies revealed that addition of IL-2, IL-12, and IL-18 to the culture conditions synergistically enhances the expression of CTLA- 4 , whereas TGF- $\beta$ showed an adverse effect on CTLA-4 expression in murine NK cells [205]. This receptor has been studied intensively in T cells, and showed that it competes with CD28 for binding with CD80/CD86 on APCs, and that successful interaction blocks the cytotoxic function of NK cells [210,211]. CTLA-4 represents a critical checkpoint molecule as its mutation causes a complex disorder with immunodeficiency, infections, autoimmunity, and immunological disorders $[207,209]$. CTLA-4-blocking antibodies have been successfully trialled in murine cancer models, and are currently being implemented against human tumors [212-214]. Moreover, Tregs also express CTLA-4 and mediate its suppressive function [215]. In Cetuximab-treated head and neck cancer patients, CTLA-4-positive Tregs correlate with poor prognosis and suppression of NK cell cytotoxicity [216]. CTLA-4 antibody blockade increased CD4 ${ }^{+} \mathrm{T}$ cell proliferation, IL-2 production, and promotes proliferation and the effector function of NK cells. In addition to this, CTLA-4 blocking can relieve Tregs-mediated suppression of NK cell-cytotoxicity, and increase $\mathrm{CD} 4^{+} \mathrm{T}$ cell proliferation, enhance NK cell-mediated ADCC against Ipilimumab (an anti-CTLA-4 monoclonal antibody)-tagged target cells [203,217-219]. Accordingly, blocking or limiting CTLA-4 availability to its cognate ligands increases the availability for CD28, thus permitting the activation of potentially self-reactive intratumoral NK cells [220]. In 2010, a phase III clinical trial of Ipilimumab showed better efficacy and prolonged overall survival of metastatic melanoma patients [221], and was approved one year later by the Food and Drug Administration (FDA) for the treatment of metastatic melanoma. 
Recently, it was also approved for the treatment of metastatic colorectal cancer and renal cell carcinoma in combination with anti-PD-1-blocking antibody, i.e., Nivolumab [222]. Furthermore, Tremelimumab, a human CTLA-4 IgG2 antibody, has been introduced by AstraZeneca, and phase II/III clinical trials in melanoma patients showed a durable response, but did not show a significant survival benefit as compared to first-line therapy (Table 1) [223,224].

Last, but not least, programmed cell death (PD-1) is expressed on NK cells and interacts with PD-L1 or PD-L2, and their interactions have led to T cell inhibition, resulting in immune escape $[225,226]$. Healthy individuals express a low level of PD-1 expression, which is upregulated in peripheral and tumour-infiltrating NK cells [227]. Comparisons of PD- $1^{+} \mathrm{NK}$ cells and PD-1 ${ }^{-} \mathrm{NK}$ cells have revealed the role of PD-1 in NK cell exhaustion with irregular cytotoxic and cytokine production [228]. Furthermore, a correlation between PD-1 expression and its impact on NK cell-mediated antitumor activity and disrupting PD-1 and PD-L1 interaction by blocking antibody led to partial restoration [229]. On the other hand, blocking of PD-L1 has shown to improve the NK cell functionality. In several studies, Avelumab, an anti-PD-L1 antibody-mediated ADCC toward multiple types of carcinoma cells, caused destruction of breast cancer cells and production of cytokines by Avelumab-triggered NK cells [230,231]. However, checkpoint inhibition is very complex and needs further investigation. Nivolumab (Bristol-Myers Squibb, New York (United States)) is another human PD-1 monoclonal antibody (IgG4) that has been studied in a clinical trial, and its phase I study has shown good efficacy in Non-small-cell lung carcinoma (NSCLC), melanoma, and renal cell carcinoma (Table 1) [53]. The US FDA has already approved Nivolumab for the treatment of melanoma, squamous cell lung cancer, Hodgkin's lymphoma, and renal cell carcinoma. Other PD-1 inhibitors, such as AMP-224 and CT-011, are under clinical investigation [232,233].

\section{Genetic Modification of NK Cells}

A new era of cancer immunotherapy has begun with genetic modification of immune cells. Chimeric antigen receptors (CARs) are recombinant receptors, commonly formed from mAb-derived single-chain variable fragments $(\mathrm{scFv})$ that provide both antigen-binding and immune-cell-activating functions [234,235]. Since various malignant cells have been shown to be able to escape from CAR-engineered cells, second and third generations of CARs including one or more endodomains for binding costimulatory molecules (i.e., CD28, 4-1BB, OX40, and 2B4) have been generated [236]. CAR binding to tumor antigens elicits downstream signalling via its intracellular domains to trigger immune cell activation, proliferation, and function.

The first lymphocytes to be genetically modified with CAR technology were T cells, and this laid the groundwork for large-scale use of autologous CAR T cells in clinical applications to treat several types of human cancers. The FDA has recently given approval to CD19 CAR T-cell therapy to treat B cell acute lymphoid leukemia (ALL) and NHL [237]. However, the manufacturing of autologous CAR T cells is logistically challenging and expensive [238]. On the other hand, allogenic CAR-modified NK cells are attractive contenders for targeting malignant cells in the absence of a prior antigen sensitization, and extensive research efforts are ongoing to generate an off-the-shelf cellular product [239]. The CD28 motif is not naturally expressed, and their advantage in NK cell is still in discussion [240]. Currently, one clinical trial is investigating the safety and relative efficacy of CAR-CD19-CD28-zeta-2A-iCasp9-IL15-transduced cord blood-NK cells (CB-NK) in patients with relapsed/refractory CD19+ B lymphoid malignancies (NCT03056339). The advantage of CD28 costimulatory signalling is still not approved, but looks promising.

4-1BB is a costimultory receptor expressed on activated NK cells [57]. Recently, a pilot study of redirected haploidentical NK cells was first expanded by coculture with the cell line K562-mb15-41BBL and IL-2 (NCT01974479). Similar to 4-1BB, OX40 is another checkpoint costimulatory receptor that modulates cell survival and cytokine release [93]. OX40 is often part of third-generation CAR constructs in T cells [241], but has still not been investigated in CAR constructs for primary NK cells. 
This technology would allow us to investigate costimulatory receptor signalling through endodomains of CAR constructs.

\section{Concluding Remarks}

Checkpoint-based cancer immunotherapy is a rapidly evolving field. Modulatory and inhibitory checkpoint functions are promising targets to enhance NK cell effector function and induce an antitumor response. However, tumor cells evade these mechanisms and dominate NK cell-based immune responses. Interaction of NK cells and tumor cells via receptor-ligand interaction is necessary to explore for the development of NK cell-based immunotherapy against cancers. Immunotherapy can enhance the antitumor immunity of the host body, and blockade of the immune checkpoint is an effective strategy to relieve the exhaustion of NK cells. Immunotherapy with checkpoint inhibitors has significantly improved the clinical outcome of various patients, but there is a need for further improvement. A transition from monotherapy to a combined synergistic approach of a distinct group of checkpoint molecules along with costimulatory molecules is on the rise in the field of immunotherapy development. Combined treatment shows higher potential in a fraction of patients that respond to medication in various cancer types. Therefore, discovering new checkpoint molecules and connecting molecules between the innate and adaptive immune system, and evaluating them for combination therapies has to be a priority in future research.

Author Contributions: S.K.S.C. performed the review of the literature, wrote and edited the manuscript. S.K. and U.K. supervise the script. All authors have read and agreed to the published version of the manuscript.

Funding: This work was supported by a grant to UK from the European Commission (Marie-Sklodowska-Curie Actions H2020-MSCA-ITN-2017-765104 MATURE-NK). SKSC is a fellow in this project.

Acknowledgments: The authors appreciate the PD Michael Morgan (Institute of Experimental hematology, Hannover Medical School, Germany) and Sukhraj P. Dhami (Royal College of Surgeons in Ireland (RCSI), Ireland) for their valuable \& profound feedback.

Conflicts of Interest: The authors declare no conflict of interest.

\section{References}

1. Matsunaga, T.; Rahman, A. What brought the adaptive immune system to vertebrates? The jaw hypothesis and the seahorse. Immunol. Rev. 1998, 166, 177-186. [CrossRef]

2. Oldham, R.K. Natural killer cells: Artifact to reality: An odyssey in biology. Cancer Metastasis Rev. 1983, 2, 323-336. [CrossRef] [PubMed]

3. Vivier, E.; Tomasello, E.; Baratin, M.; Walzer, T.; Ugolini, S. Functions of natural killer cells. Nat. Immunol. 2008, 9, 503-510. [CrossRef]

4. Colucci, F.; Caligiuri, M.A.; Di Santo, J.P. What does it take to make a natural killer? Nat. Rev. Immunol. 2003, 3, 413-425. [CrossRef]

5. Veluchamy, J.P.; Kok, N.; van der Vliet, H.J.; Verheul, H.M.W.; de Gruijl, T.D.; Spanholtz, J. The Rise of Allogeneic Natural Killer Cells as a Platform for Cancer Immunotherapy: Recent Innovations and Future Developments. Front. Immunol. 2017, 8, 631. [CrossRef]

6. Wu, J.; Lanier, L.L. Natural killer cells and cancer. Adv. Cancer Res. 2003, 90, 127-156.

7. Raulet, D.H.; Guerra, N. Oncogenic stress sensed by the immune system: Role of natural killer cell receptors. Nat. Rev. Immunol. 2009, 9, 568-580. [CrossRef] [PubMed]

8. Farnault, L.; Sanchez, C.; Baier, C.; Le Treut, T.; Costello, R.T. Hematological malignancies escape from NK cell innate immune surveillance: Mechanisms and therapeutic implications. Clin. Dev. Immunol. 2012, 2012, 421702. [CrossRef] [PubMed]

9. Lanier, L.L. Follow the leader: NK cell receptors for classical and nonclassical MHC class I. Cell 1998, 92, 705-707. [CrossRef]

10. Lanier, L.L. Up on the tightrope: Natural killer cell activation and inhibition. Nat. Immunol. 2008, 9, 495-502. [CrossRef]

11. Lanier, L.L. Activating and inhibitory NK cell receptors. Adv. Exp. Med. Biol. 1998, 452, 13-18. [PubMed] 
12. Vivier, E.; Nunes, J.A.; Vely, F. Natural killer cell signaling pathways. Science 2004, 306, 1517-1519. [CrossRef] [PubMed]

13. Della Chiesa, M.; Carlomagno, S.; Frumento, G.; Balsamo, M.; Cantoni, C.; Conte, R.; Moretta, L.; Moretta, A.; Vitale, M. The tryptophan catabolite L-kynurenine inhibits the surface expression of NKp46and NKG2D-activating receptors and regulates NK-cell function. Blood 2006, 108, 4118-4125. [CrossRef]

14. Vitale, M.; Cantoni, C.; Pietra, G.; Mingari, M.C.; Moretta, L. Effect of tumor cells and tumor microenvironment on NK-cell function. Eur. J. Immunol. 2014, 44, 1582-1592. [CrossRef]

15. Pietra, G.; Manzini, C.; Rivara, S.; Vitale, M.; Cantoni, C.; Petretto, A.; Balsamo, M.; Conte, R.; Benelli, R.; Minghelli, S.; et al. Melanoma cells inhibit natural killer cell function by modulating the expression of activating receptors and cytolytic activity. Cancer Res. 2012, 72, 1407-1415. [CrossRef] [PubMed]

16. Ljunggren, H.G.; Karre, K. In search of the 'missing self': MHC molecules and NK cell recognition. Immunol. Today 1990, 11, 237-244. [CrossRef]

17. Deng, W.; Gowen, B.G.; Zhang, L.; Wang, L.; Lau, S.; Iannello, A.; Xu, J.; Rovis, T.L.; Xiong, N.; Raulet, D.H. Antitumor immunity. A shed NKG2D ligand that promotes natural killer cell activation and tumor rejection. Science 2015, 348, 136-139. [CrossRef]

18. Semeraro, M.; Rusakiewicz, S.; Minard-Colin, V.; Delahaye, N.F.; Enot, D.; Vely, F.; Marabelle, A.; Papoular, B.; Piperoglou, C.; Ponzoni, M.; et al. Clinical impact of the NKp30/B7-H6 axis in high-risk neuroblastoma patients. Sci. Transl. Med. 2015, 7, 283ra55. [CrossRef]

19. Garni-Wagner, B.A.; Purohit, A.; Mathew, P.A.; Bennett, M.; Kumar, V. A novel function-associated molecule related to non-MHC-restricted cytotoxicity mediated by activated natural killer cells and T cells. J. Immunol. 1993, 151, 60-70.

20. Makkouk, A.; Chester, C.; Kohrt, H.E. Rationale for anti-CD137 cancer immunotherapy. Eur. J. Cancer 2016, 54, 112-119. [CrossRef]

21. Seidel, U.J.; Schlegel, P.; Lang, P. Natural killer cell mediated antibody-dependent cellular cytotoxicity in tumor immunotherapy with therapeutic antibodies. Front. Immunol. 2013, 4, 76. [CrossRef] [PubMed]

22. Sojka, D.K.; Bruniquel, D.; Schwartz, R.H.; Singh, N.J. IL-2 secretion by CD4+ T cells in vivo is rapid, transient, and influenced by TCR-specific competition. J. Immunol. 2004, 172, 6136-6143. [CrossRef] [PubMed]

23. Wang, K.S.; Ritz, J.; Frank, D.A. IL-2 induces STAT4 activation in primary NK cells and NK cell lines, but not in T cells. J. Immunol. 1999, 162, 299-304. [PubMed]

24. Niehrs, A.; Altfeld, M. Regulation of NK-Cell Function by HLA Class II. Front. Cell. Infect. Microbiol. 2020, 10, 55. [CrossRef]

25. Goyvaerts, C.; Breckpot, K. Pros and Cons of Antigen-Presenting Cell Targeted Tumor Vaccines. J. Immunol. Res. 2015, 2015, 785634. [CrossRef]

26. Ziblat, A.; Nunez, S.Y.; Raffo Iraolagoitia, X.L.; Spallanzani, R.G.; Torres, N.I.; Sierra, J.M.; Secchiari, F.; Domaica, C.I.; Fuertes, M.B.; Zwirner, N.W. Interleukin (IL)-23 Stimulates IFN-gamma Secretion by CD56(bright) Natural Killer Cells and Enhances IL-18-Driven Dendritic Cells Activation. Front. Immunol. 2017, 8, 1959. [CrossRef] [PubMed]

27. Ziblat, A.; Domaica, C.I.; Spallanzani, R.G.; Iraolagoitia, X.L.; Rossi, L.E.; Avila, D.E.; Torres, N.I.; Fuertes, M.B.; Zwirner, N.W. IL-27 stimulates human NK-cell effector functions and primes NK cells for IL-18 responsiveness. Eur. J. Immunol. 2015, 45, 192-202. [CrossRef]

28. Zwirner, N.W.; Ziblat, A. Regulation of NK Cell Activation and Effector Functions by the IL-12 Family of Cytokines: The Case of IL-27. Front. Immunol. 2017, 8, 25. [CrossRef]

29. Bluman, E.M.; Bartynski, K.J.; Avalos, B.R.; Caligiuri, M.A. Human natural killer cells produce abundant macrophage inflammatory protein-1 alpha in response to monocyte-derived cytokines. J. Clin. Invest. 1996, 97, 2722-2727. [CrossRef]

30. Chan, C.J.; Smyth, M.J.; Martinet, L. Molecular mechanisms of natural killer cell activation in response to cellular stress. Cell Death Differ. 2014, 21, 5-14. [CrossRef]

31. Vales-Gomez, M.; Chisholm, S.E.; Cassady-Cain, R.L.; Roda-Navarro, P.; Reyburn, H.T. Selective induction of expression of a ligand for the NKG2D receptor by proteasome inhibitors. Cancer Res. 2008, 68, 1546-1554. [CrossRef] [PubMed]

32. Hodge, D.R.; Hurt, E.M.; Farrar, W.L. The role of IL-6 and STAT3 in inflammation and cancer. Eur. J. Cancer 2005, 41, 2502-2512. [CrossRef] [PubMed] 
33. Biswas, S.; Chytil, A.; Washington, K.; Romero-Gallo, J.; Gorska, A.E.; Wirth, P.S.; Gautam, S.; Moses, H.L.; Grady, W.M. Transforming growth factor beta receptor type II inactivation promotes the establishment and progression of colon cancer. Cancer Res. 2004, 64, 4687-4692. [CrossRef]

34. Romagne, F.; Andre, P.; Spee, P.; Zahn, S.; Anfossi, N.; Gauthier, L.; Capanni, M.; Ruggeri, L.; Benson, D.M., Jr.; Blaser, B.W.; et al. Preclinical characterization of 1-7F9, a novel human anti-KIR receptor therapeutic antibody that augments natural killer-mediated killing of tumor cells. Blood 2009, 114, 2667-2677. [CrossRef] [PubMed]

35. Wu, J.D.; Higgins, L.M.; Steinle, A.; Cosman, D.; Haugk, K.; Plymate, S.R. Prevalent expression of the immunostimulatory MHC class I chain-related molecule is counteracted by shedding in prostate cancer. J. Clin. Invest. 2004, 114, 560-568. [CrossRef] [PubMed]

36. Campoli, M.; Ferrone, S. Tumor escape mechanisms: Potential role of soluble HLA antigens and NK cells activating ligands. Tissue Antigens 2008, 72, 321-334. [CrossRef] [PubMed]

37. Sanchez-Correa, B.; Gayoso, I.; Bergua, J.M.; Casado, J.G.; Morgado, S.; Solana, R.; Tarazona, R. Decreased expression of DNAM-1 on NK cells from acute myeloid leukemia patients. Immunol. Cell Biol. 2012, 90, 109-115. [CrossRef]

38. Kearney, C.J.; Ramsbottom, K.M.; Voskoboinik, I.; Darcy, P.K.; Oliaro, J. Loss of DNAM-1 ligand expression by acute myeloid leukemia cells renders them resistant to NK cell killing. OncoImmunology 2016, 5, e1196308. [CrossRef]

39. Bi, J.; Tian, Z. NK Cell Exhaustion. Front. Immunol. 2017, 8, 760. [CrossRef]

40. Lazarova, M.; Steinle, A. Impairment of NKG2D-Mediated Tumor Immunity by TGF-beta. Front. Immunol. 2019, 10, 2689. [CrossRef]

41. Groth, A.; Kloss, S.; von Strandmann, E.P.; Koehl, U.; Koch, J. Mechanisms of tumor and viral immune escape from natural killer cell-mediated surveillance. J. Innate Immun. 2011, 3, 344-354. [CrossRef] [PubMed]

42. Elkabets, M.; Ribeiro, V.S.; Dinarello, C.A.; Ostrand-Rosenberg, S.; Di Santo, J.P.; Apte, R.N.; Vosshenrich, C.A. IL-1beta regulates a novel myeloid-derived suppressor cell subset that impairs NK cell development and function. Eur. J. Immunol. 2010, 40, 3347-3357. [CrossRef]

43. Li, H.; Han, Y.; Guo, Q.; Zhang, M.; Cao, X. Cancer-expanded myeloid-derived suppressor cells induce anergy of NK cells through membrane-bound TGF-beta 1. J. Immunol. 2009, 182, 240-249. [CrossRef] [PubMed]

44. Nunez, S.Y.; Ziblat, A.; Secchiari, F.; Torres, N.I.; Sierra, J.M.; Raffo Iraolagoitia, X.L.; Araya, R.E.; Domaica, C.I.; Fuertes, M.B.; Zwirner, N.W. Human M2 Macrophages Limit NK Cell Effector Functions through Secretion of TGF-beta and Engagement of CD85j. J. Immunol. 2018, 200, 1008-1015. [CrossRef] [PubMed]

45. Sitrin, J.; Ring, A.; Garcia, K.C.; Benoist, C.; Mathis, D. Regulatory T cells control NK cells in an insulitic lesion by depriving them of IL-2. J. Exp. Med. 2013, 210, 1153-1165. [CrossRef]

46. Li, T.; Yang, Y.; Hua, X.; Wang, G.; Liu, W.; Jia, C.; Tai, Y.; Zhang, Q.; Chen, G. Hepatocellular carcinoma-associated fibroblasts trigger NK cell dysfunction via PGE2 and IDO. Cancer Lett. 2012, 318, 154-161. [CrossRef]

47. Sarhan, D.; Palma, M.; Mao, Y.; Adamson, L.; Kiessling, R.; Mellstedt, H.; Osterborg, A.; Lundqvist, A. Dendritic cell regulation of NK-cell responses involves lymphotoxin-alpha, IL-12, and TGF-beta. Eur. J. Immunol. 2015, 45, 1783-1793. [CrossRef]

48. Zappasodi, R.; Merghoub, T.; Wolchok, J.D. Emerging Concepts for Immune Checkpoint Blockade-Based Combination Therapies. Cancer Cell 2018, 33, 581-598. [CrossRef]

49. Leach, D.R.; Krummel, M.F.; Allison, J.P. Enhancement of antitumor immunity by CTLA-4 blockade. Science 1996, 271, 1734-1736. [CrossRef]

50. Korman, A.J.; Peggs, K.S.; Allison, J.P. Checkpoint blockade in cancer immunotherapy. Adv. Immunol. 2006, 90, 297-339.

51. Pardoll, D.M. The blockade of immune checkpoints in cancer immunotherapy. Nat. Rev. Cancer 2012, 12, 252-264. [CrossRef] [PubMed]

52. Wolchok, J.D.; Chiarion-Sileni, V.; Gonzalez, R.; Rutkowski, P.; Grob, J.J.; Cowey, C.L.; Lao, C.D.; Wagstaff, J.; Schadendorf, D.; Ferrucci, P.F.; et al. Overall Survival with Combined Nivolumab and Ipilimumab in Advanced Melanoma. N. Engl. J. Med. 2017, 377, 1345-1356. [CrossRef]

53. Topalian, S.L.; Hodi, F.S.; Brahmer, J.R.; Gettinger, S.N.; Smith, D.C.; McDermott, D.F.; Powderly, J.D.; Carvajal, R.D.; Sosman, J.A.; Atkins, M.B.; et al. Safety, activity, and immune correlates of anti-PD-1 antibody in cancer. N. Engl. J. Med. 2012, 366, 2443-2454. [CrossRef] [PubMed] 
54. Robert, C.; Schachter, J.; Long, G.V.; Arance, A.; Grob, J.J.; Mortier, L.; Daud, A.; Carlino, M.S.; McNeil, C.; Lotem, M.; et al. Pembrolizumab versus Ipilimumab in Advanced Melanoma. N. Engl. J. Med. 2015, 372, 2521-2532. [CrossRef] [PubMed]

55. Nuebling, T.; Schumacher, C.E.; Hofmann, M.; Hagelstein, I.; Schmiedel, B.J.; Maurer, S.; Federmann, B.; Rothfelder, K.; Roerden, M.; Dorfel, D.; et al. The Immune Checkpoint Modulator OX40 and Its Ligand OX40L in NK-Cell Immunosurveillance and Acute Myeloid Leukemia. Cancer Immunol. Res. 2018, 6, $209-221$. [CrossRef] [PubMed]

56. Baltz, K.M.; Krusch, M.; Bringmann, A.; Brossart, P.; Mayer, F.; Kloss, M.; Baessler, T.; Kumbier, I.; Peterfi, A.; Kupka, S.; et al. Cancer immunoediting by GITR (glucocorticoid-induced TNF-related protein) ligand in humans: NK cell/tumor cell interactions. FASEB J. 2007, 21, 2442-2454. [CrossRef] [PubMed]

57. Navabi, S.; Doroudchi, M.; Tashnizi, A.H.; Habibagahi, M. Natural Killer Cell Functional Activity After 4-1BB Costimulation. Inflammation 2015, 38, 1181-1190. [CrossRef]

58. Vidard, L.; Dureuil, C.; Baudhuin, J.; Vescovi, L.; Durand, L.; Sierra, V.; Parmantier, E. CD137 (4-1BB) Engagement Fine-Tunes Synergistic IL-15- and IL-21-Driven NK Cell Proliferation. J. Immunol. 2019, 203, 676-685. [CrossRef]

59. Hurtado, J.C.; Kim, S.H.; Pollok, K.E.; Lee, Z.H.; Kwon, B.S. Potential role of 4-1BB in T cell activation. Comparison with the costimulatory molecule CD28. J. Immunol. 1995, 155, 3360-3367.

60. Shao, Z.; Schwarz, H. CD137 ligand, a member of the tumor necrosis factor family, regulates immune responses via reverse signal transduction. J. Leukoc. Biol. 2011, 89, 21-29. [CrossRef]

61. Croft, M. The role of TNF superfamily members in T-cell function and diseases. Nat. Rev. Immunol. 2009, 9, 271-285. [CrossRef] [PubMed]

62. Shuford, W.W.; Klussman, K.; Tritchler, D.D.; Loo, D.T.; Chalupny, J.; Siadak, A.W.; Brown, T.J.; Emswiler, J.; Raecho, H.; Larsen, C.P.; et al. 4-1BB costimulatory signals preferentially induce CD8+ T cell proliferation and lead to the amplification in vivo of cytotoxic T cell responses. J. Exp. Med. 1997, 186, 47-55. [CrossRef] [PubMed]

63. Wen, T.; Bukczynski, J.; Watts, T.H. 4-1BB ligand-mediated costimulation of human T cells induces CD4 and CD8 T cell expansion, cytokine production, and the development of cytolytic effector function. J. Immunol. 2002, 168, 4897-4906. [CrossRef]

64. Vinay, D.S.; Kwon, B.S. Differential expression and costimulatory effect of 4-1BB (CD137) and CD28 molecules on cytokine-induced murine CD8(+) Tc1 and Tc2 cells. Cell. Immunol. 1999, 192, 63-71. [CrossRef] [PubMed]

65. Vinay, D.S.; Kwon, B.S. Role of 4-1BB in immune responses. Semin. Immunol. 1998, 10, 481-489. [CrossRef]

66. Melero, I.; Johnston, J.V.; Shufford, W.W.; Mittler, R.S.; Chen, L. NK1.1 cells express 4-1BB (CDw137) costimulatory molecule and are required for tumor immunity elicited by anti-4-1BB monoclonal antibodies. Cell. Immunol. 1998, 190, 167-172. [CrossRef] [PubMed]

67. Wilcox, R.A.; Tamada, K.; Strome, S.E.; Chen, L. Signaling through NK cell-associated CD137 promotes both helper function for CD8+ cytolytic T cells and responsiveness to IL-2 but not cytolytic activity. J. Immunol. 2002, 169, 4230-4236. [CrossRef]

68. Wong, H.Y.; Schwarz, H. CD137 / CD137 ligand signalling regulates the immune balance: A potential target for novel immunotherapy of autoimmune diseases. J. Autoimmun. 2020. [CrossRef]

69. Kang, Y.J.; Kim, S.O.; Shimada, S.; Otsuka, M.; Seit-Nebi, A.; Kwon, B.S.; Watts, T.H.; Han, J. Cell surface 4-1BBL mediates sequential signaling pathways 'downstream' of TLR and is required for sustained TNF production in macrophages. Nat. Immunol. 2007, 8, 601-609. [CrossRef] [PubMed]

70. Dharmadhikari, B.; Wu, M.; Abdullah, N.S.; Rajendran, S.; Ishak, N.D.; Nickles, E.; Harfuddin, Z.; Schwarz, H. CD137 and CD137L signals are main drivers of type 1, cell-mediated immune responses. Oncolmmunology 2016, 5, e1113367. [CrossRef]

71. Wilcox, R.A.; Chapoval, A.I.; Gorski, K.S.; Otsuji, M.; Shin, T.; Flies, D.B.; Tamada, K.; Mittler, R.S.; Tsuchiya, H.; Pardoll, D.M.; et al. Cutting edge: Expression of functional CD137 receptor by dendritic cells. J. Immunol. 2002, 168, 4262-4267. [CrossRef] [PubMed]

72. Freeman, Z.T.; Nirschl, T.R.; Hovelson, D.H.; Johnston, R.J.; Engelhardt, J.J.; Selby, M.J.; Kochel, C.M.; Lan, R.Y.; Zhai, J.; Ghasemzadeh, A.; et al. A conserved intratumoral regulatory T cell signature identifies 4-1BB as a pan-cancer target. J. Clin. Invest. 2020, 130, 1405-1416. [CrossRef] [PubMed] 
73. Houot, R.; Goldstein, M.J.; Kohrt, H.E.; Myklebust, J.H.; Alizadeh, A.A.; Lin, J.T.; Irish, J.M.; Torchia, J.A.; Kolstad, A.; Chen, L.; et al. Therapeutic effect of CD137 immunomodulation in lymphoma and its enhancement by Treg depletion. Blood 2009, 114, 3431-3438. [CrossRef]

74. Chester, C.; Ambulkar, S.; Kohrt, H.E. 4-1BB agonism: Adding the accelerator to cancer immunotherapy. Cancer Immunol. Immunother. 2016, 65, 1243-1248. [CrossRef]

75. Souza-Fonseca-Guimaraes, F.; Blake, S.J.; Makkouk, A.; Chester, C.; Kohrt, H.E.; Smyth, M.J. Anti-CD137 enhances anti-CD20 therapy of systemic B-cell lymphoma with altered immune homeostasis but negligible toxicity. OncoImmunology 2016, 5, e1192740. [CrossRef]

76. Kohrt, H.E.; Houot, R.; Goldstein, M.J.; Weiskopf, K.; Alizadeh, A.A.; Brody, J.; Muller, A.; Pachynski, R.; Czerwinski, D.; Coutre, S.; et al. CD137 stimulation enhances the antilymphoma activity of anti-CD20 antibodies. Blood 2019, 134, 658.

77. Kohrt, H.E.; Houot, R.; Weiskopf, K.; Goldstein, M.J.; Scheeren, F.; Czerwinski, D.; Colevas, A.D.; Weng, W.K.; Clarke, M.F.; Carlson, R.W.; et al. Stimulation of natural killer cells with a CD137-specific antibody enhances trastuzumab efficacy in xenotransplant models of breast cancer. J. Clin. Invest. 2012, 122, 1066-1075. [CrossRef]

78. Kohrt, H.E.; Colevas, A.D.; Houot, R.; Weiskopf, K.; Goldstein, M.J.; Lund, P.; Mueller, A.; Sagiv-Barfi, I.; Marabelle, A.; Lira, R.; et al. Targeting CD137 enhances the efficacy of cetuximab. J. Clin. Invest. 2014, 124, 2668-2682. [CrossRef]

79. Yonezawa, A.; Dutt, S.; Chester, C.; Kim, J.; Kohrt, H.E. Boosting Cancer Immunotherapy with Anti-CD137 Antibody Therapy. Clin. Cancer Res. 2015, 21, 3113-3120. [CrossRef]

80. Segal, N.H.; He, A.R.; Doi, T.; Levy, R.; Bhatia, S.; Pishvaian, M.J.; Cesari, R.; Chen, Y.; Davis, C.B.; Huang, B.; et al. Phase I Study of Single-Agent Utomilumab (PF-05082566), a 4-1BB/CD137 Agonist, in Patients with Advanced Cancer. Clin. Cancer Res. 2018, 24, 1816-1823. [CrossRef]

81. Tolcher, A.W.; Sznol, M.; Hu-Lieskovan, S.; Papadopoulos, K.P.; Patnaik, A.; Rasco, D.W.; Di Gravio, D.; Huang, B.; Gambhire, D.; Chen, Y.; et al. Phase Ib Study of Utomilumab (PF-05082566), a 4-1BB/CD137 Agonist, in Combination with Pembrolizumab (MK-3475) in Patients with Advanced Solid Tumors. Clin. Cancer Res. 2017, 23, 5349-5357. [CrossRef]

82. Calderhead, D.M.; Buhlmann, J.E.; van den Eertwegh, A.J.; Claassen, E.; Noelle, R.J.; Fell, H.P. Cloning of mouse Ox40: A T cell activation marker that may mediate T-B cell interactions. J. Immunol. 1993, 151, 5261-5271.

83. Willoughby, J.; Griffiths, J.; Tews, I.; Cragg, M.S. OX40: Structure and function—What questions remain? Mol. Immunol. 2017, 83, 13-22. [CrossRef] [PubMed]

84. Sun, G.; Sun, X.; Li, W.; Liu, K.; Tian, D.; Dong, Y.; Sun, X.; Xu, H.; Zhang, D. Critical role of OX40 in the expansion and survival of CD4 T-cell-derived double-negative T cells. Cell Death Dis. 2018, 9, 616. [CrossRef] [PubMed]

85. Stuber, E.; Neurath, M.; Calderhead, D.; Fell, H.P.; Strober, W. Cross-linking of OX40 ligand, a member of the $\mathrm{TNF} / \mathrm{NGF}$ cytokine family, induces proliferation and differentiation in murine splenic B cells. Immunity 1995, 2, 507-521. [CrossRef]

86. Ohshima, Y.; Tanaka, Y.; Tozawa, H.; Takahashi, Y.; Maliszewski, C.; Delespesse, G. Expression and function of OX40 ligand on human dendritic cells. J. Immunol. 1997, 159, 3838-3848.

87. Takasawa, N.; Ishii, N.; Higashimura, N.; Murata, K.; Tanaka, Y.; Nakamura, M.; Sasaki, T.; Sugamura, K. Expression of gp34 (OX40 ligand) and OX40 on human T cell clones. Jpn. J. Cancer Res. 2001, 92, 377-382. [CrossRef]

88. Gramaglia, I.; Weinberg, A.D.; Lemon, M.; Croft, M. Ox-40 ligand: A potent costimulatory molecule for sustaining primary CD4 T cell responses. J. Immunol. 1998, 161, 6510-6517.

89. Weinberg, A.D.; Wegmann, K.W.; Funatake, C.; Whitham, R.H. Blocking OX-40/OX-40 ligand interaction in vitro and in vivo leads to decreased $\mathrm{T}$ cell function and amelioration of experimental allergic encephalomyelitis. J. Immunol. 1999, 162, 1818-1826.

90. Murata, K.; Ishii, N.; Takano, H.; Miura, S.; Ndhlovu, L.C.; Nose, M.; Noda, T.; Sugamura, K. Impairment of antigen-presenting cell function in mice lacking expression of OX40 ligand. J. Exp. Med. 2000, 191, 365-374. [CrossRef] 
91. Gramaglia, I.; Jember, A.; Pippig, S.D.; Weinberg, A.D.; Killeen, N.; Croft, M. The OX40 costimulatory receptor determines the development of CD4 memory by regulating primary clonal expansion. J. Immunol. 2000, 165, 3043-3050. [CrossRef] [PubMed]

92. Rogers, P.R.; Song, J.; Gramaglia, I.; Killeen, N.; Croft, M. OX40 promotes Bcl-xL and Bcl-2 expression and is essential for long-term survival of CD4 T cells. Immunity 2001, 15, 445-455. [CrossRef]

93. Zingoni, A.; Sornasse, T.; Cocks, B.G.; Tanaka, Y.; Santoni, A.; Lanier, L.L. Cross-talk between activated human NK cells and CD4+ T cells via OX40-OX40 ligand interactions. J. Immunol. 2004, 173, 3716-3724. [CrossRef] [PubMed]

94. Croft, M. Control of immunity by the TNFR-related molecule OX40 (CD134). Annu. Rev. Immunol. 2010, 28, 57-78. [CrossRef] [PubMed]

95. Liu, C.; Lou, Y.; Lizee, G.; Qin, H.; Liu, S.; Rabinovich, B.; Kim, G.J.; Wang, Y.H.; Ye, Y.; Sikora, A.G.; et al. Plasmacytoid dendritic cells induce NK cell-dependent, tumor antigen-specific T cell cross-priming and tumor regression in mice. J. Clin. Invest. 2008, 118, 1165-1175. [CrossRef]

96. Turaj, A.H.; Cox, K.L.; Penfold, C.A.; French, R.R.; Mockridge, C.I.; Willoughby, J.E.; Tutt, A.L.; Griffiths, J.; Johnson, P.W.M.; Glennie, M.J.; et al. Augmentation of CD134 (OX40)-dependent NK anti-tumour activity is dependent on antibody cross-linking. Sci Rep. 2018, 8, 2278. [CrossRef]

97. Hanna, J.; Bechtel, P.; Zhai, Y.; Youssef, F.; McLachlan, K.; Mandelboim, O. Novel insights on human NK cells' immunological modalities revealed by gene expression profiling. J. Immunol. 2004, 173, 6547-6563. [CrossRef]

98. Curti, B.D.; Kovacsovics-Bankowski, M.; Morris, N.; Walker, E.; Chisholm, L.; Floyd, K.; Walker, J.; Gonzalez, I.; Meeuwsen, T.; Fox, B.A.; et al. OX40 is a potent immune-stimulating target in late-stage cancer patients. Cancer Res. 2013, 73, 7189-7198. [CrossRef]

99. Ronchetti, S.; Zollo, O.; Bruscoli, S.; Agostini, M.; Bianchini, R.; Nocentini, G.; Ayroldi, E.; Riccardi, C. GITR, a member of the TNF receptor superfamily, is costimulatory to mouse T lymphocyte subpopulations. Eur. J. Immunol. 2004, 34, 613-622. [CrossRef]

100. Nocentini, G.; Bartoli, A.; Ronchetti, S.; Giunchi, L.; Cupelli, A.; Delfino, D.; Migliorati, G.; Riccardi, C. Gene structure and chromosomal assignment of mouse GITR, a member of the tumor necrosis factor/nerve growth factor receptor family. DNA Cell Biol. 2000, 19, 205-217. [CrossRef]

101. Nocentini, G.; Riccardi, C. GITR: A multifaceted regulator of immunity belonging to the tumor necrosis factor receptor superfamily. Eur. J. Immunol. 2005, 35, 1016-1022. [CrossRef]

102. Hurtado, J.C.; Kim, Y.J.; Kwon, B.S. Signals through 4-1BB are costimulatory to previously activated splenic T cells and inhibit activation-induced cell death. J. Immunol. 1997, 158, 2600-2609.

103. Ji, H.B.; Liao, G.; Faubion, W.A.; Abadia-Molina, A.C.; Cozzo, C.; Laroux, F.S.; Caton, A.; Terhorst, C. Cutting edge: The natural ligand for glucocorticoid-induced TNF receptor-related protein abrogates regulatory $\mathrm{T}$ cell suppression. J. Immunol. 2004, 172, 5823-5827. [CrossRef]

104. Li, Z.; Mahesh, S.P.; Kim, B.J.; Buggage, R.R.; Nussenblatt, R.B. Expression of glucocorticoid induced TNF receptor family related protein (GITR) on peripheral $\mathrm{T}$ cells from normal human donors and patients with non-infectious uveitis. J. Autoimmun. 2003, 21, 83-92. [CrossRef]

105. Shin, H.H.; Lee, M.H.; Kim, S.G.; Lee, Y.H.; Kwon, B.S.; Choi, H.S. Recombinant glucocorticoid induced tumor necrosis factor receptor (rGITR) induces NOS in murine macrophage. FEBS Lett. 2002, 514, 275-280. [CrossRef]

106. Tian, J.; Ma, J.; Ma, K.; Ma, B.; Tang, X.; Baidoo, S.E.; Tong, J.; Yan, J.; Lu, L.; Xu, H.; et al. Up-regulation of GITRL on dendritic cells by WGP improves anti-tumor immunity in murine Lewis lung carcinoma. PLoS ONE 2012, 7, e46936. [CrossRef] [PubMed]

107. Liu, B.; Li, Z.; Mahesh, S.P.; Pantanelli, S.; Hwang, F.S.; Siu, W.O.; Nussenblatt, R.B. Glucocorticoid-induced tumor necrosis factor receptor negatively regulates activation of human primary natural killer (NK) cells by blocking proliferative signals and increasing NK cell apoptosis. J. Biol. Chem. 2008, 283, 8202-8210. [CrossRef] [PubMed]

108. Shevach, E.M.; Stephens, G.L. The GITR-GITRL interaction: Co-stimulation or contrasuppression of regulatory activity? Nat. Rev. Immunol. 2006, 6, 613-618. [CrossRef] [PubMed]

109. Snell, L.M.; Lin, G.H.; McPherson, A.J.; Moraes, T.J.; Watts, T.H. T-cell intrinsic effects of GITR and 4-1BB during viral infection and cancer immunotherapy. Immunol. Rev. 2011, 244, 197-217. [CrossRef] [PubMed] 
110. Hanabuchi, S.; Watanabe, N.; Wang, Y.H.; Wang, Y.H.; Ito, T.; Shaw, J.; Cao, W.; Qin, F.X.; Liu, Y.J. Human plasmacytoid predendritic cells activate NK cells through glucocorticoid-induced tumor necrosis factor receptor-ligand (GITRL). Blood 2006, 107, 3617-3623. [CrossRef]

111. Ko, K.; Yamazaki, S.; Nakamura, K.; Nishioka, T.; Hirota, K.; Yamaguchi, T.; Shimizu, J.; Nomura, T.; Chiba, T.; Sakaguchi, S. Treatment of advanced tumors with agonistic anti-GITR mAb and its effects on tumor-infiltrating Foxp3+CD25+CD4+ regulatory T cells. J. Exp. Med. 2005, 202, 885-891. [CrossRef]

112. Cohen, A.D.; Schaer, D.A.; Liu, C.; Li, Y.; Hirschhorn-Cymmerman, D.; Kim, S.C.; Diab, A.; Rizzuto, G.; Duan, F.; Perales, M.A.; et al. Agonist anti-GITR monoclonal antibody induces melanoma tumor immunity in mice by altering regulatory $\mathrm{T}$ cell stability and intra-tumor accumulation. PLoS ONE 2010, 5, e10436. [CrossRef] [PubMed]

113. Turk, M.J.; Guevara-Patino, J.A.; Rizzuto, G.A.; Engelhorn, M.E.; Sakaguchi, S.; Houghton, A.N. Concomitant tumor immunity to a poorly immunogenic melanoma is prevented by regulatory T cells. J. Exp. Med. 2004, 200, 771-782. [CrossRef]

114. Zappasodi, R.; Sirard, C.; Li, Y.; Budhu, S.; Abu-Akeel, M.; Liu, C.; Yang, X.; Zhong, H.; Newman, W.; Qi, J.; et al. Rational design of anti-GITR-based combination immunotherapy. Nat. Med. 2019, 25, 759-766. [CrossRef]

115. Marhelava, K.; Pilch, Z.; Bajor, M.; Graczyk-Jarzynka, A.; Zagozdzon, R. Targeting Negative and Positive Immune Checkpoints with Monoclonal Antibodies in Therapy of Cancer. Cancers 2019, 11, 1756. [CrossRef]

116. Harjunpaa, H.; Guillerey, C. TIGIT as an emerging immune checkpoint. Clin. Exp. Immunol. 2020, 200, 108-119. [CrossRef] [PubMed]

117. Georgiev, H.; Ravens, I.; Papadogianni, G.; Bernhardt, G. Coming of Age: CD96 Emerges as Modulator of Immune Responses. Front. Immunol. 2018, 9, 1072. [CrossRef]

118. Krummel, M.F.; Allison, J.P. CD28 and CTLA-4 have opposing effects on the response of T cells to stimulation. J. Exp. Med. 1995, 182, 459-465. [CrossRef]

119. Long, L.; Zhang, X.; Chen, F.; Pan, Q.; Phiphatwatchara, P.; Zeng, Y.; Chen, H. The promising immune checkpoint LAG-3: From tumor microenvironment to cancer immunotherapy. Genes Cancer 2018, 9, 176-189.

120. Pesce, S.; Greppi, M.; Grossi, F.; Del Zotto, G.; Moretta, L.; Sivori, S.; Genova, C.; Marcenaro, E. PD/1-PD-Ls Checkpoint: Insight on the Potential Role of NK Cells. Front. Immunol. 2019, 10, 1242. [CrossRef]

121. He, Y.; Cao, J.; Zhao, C.; Li, X.; Zhou, C.; Hirsch, F.R. TIM-3, a promising target for cancer immunotherapy. Onco Targets Ther. 2018, 11, 7005-7009. [CrossRef]

122. Daly, J.; Carlsten, M.; O'Dwyer, M. Sugar Free: Novel Immunotherapeutic Approaches Targeting Siglecs and Sialic Acids to Enhance Natural Killer Cell Cytotoxicity Against Cancer. Front. Immunol. 2019, 10, 1047. [CrossRef]

123. Borrego, F.; Masilamani, M.; Kabat, J.; Sanni, T.B.; Coligan, J.E. The cell biology of the human natural killer cell CD94/NKG2A inhibitory receptor. Mol. Immunol. 2005, 42, 485-488. [CrossRef]

124. Rodriguez, J.A. HLA-mediated tumor escape mechanisms that may impair immunotherapy clinical outcomes via T-cell activation. Oncol. Lett 2017, 14, 4415-4427. [CrossRef] [PubMed]

125. Malmberg, K.J.; Levitsky, V.; Norell, H.; de Matos, C.T.; Carlsten, M.; Schedvins, K.; Rabbani, H.; Moretta, A.; Soderstrom, K.; Levitskaya, J.; et al. IFN-gamma protects short-term ovarian carcinoma cell lines from CTL lysis via a CD94/NKG2A-dependent mechanism. J. Clin. Invest. 2002, 110, 1515-1523. [CrossRef] [PubMed]

126. Talebian Yazdi, M.; van Riet, S.; van Schadewijk, A.; Fiocco, M.; van Hall, T.; Taube, C.; Hiemstra, P.S.; van der Burg, S.H. The positive prognostic effect of stromal CD8+ tumor-infiltrating T cells is restrained by the expression of HLA-E in non-small cell lung carcinoma. Oncotarget 2016, 7, 3477-3488. [CrossRef]

127. Borrego, F.; Ulbrecht, M.; Weiss, E.H.; Coligan, J.E.; Brooks, A.G. Recognition of human histocompatibility leukocyte antigen (HLA)-E complexed with HLA class I signal sequence-derived peptides by CD94/NKG2 confers protection from natural killer cell-mediated lysis. J. Exp. Med. 1998, 187, 813-818. [CrossRef] [PubMed]

128. Lee, N.; Llano, M.; Carretero, M.; Ishitani, A.; Navarro, F.; Lopez-Botet, M.; Geraghty, D.E. HLA-E is a major ligand for the natural killer inhibitory receptor CD94/NKG2A. Proc. Natl. Acad. Sci USA 1998, 95, 5199-5204. [CrossRef]

129. Llano, M.; Lee, N.; Navarro, F.; Garcia, P.; Albar, J.P.; Geraghty, D.E.; Lopez-Botet, M. HLA-E-bound peptides influence recognition by inhibitory and triggering CD94/NKG2 receptors: Preferential response to an HLA-G-derived nonamer. Eur. J. Immunol. 1998, 28, 2854-2863. [CrossRef] 
130. Mamessier, E.; Sylvain, A.; Thibult, M.L.; Houvenaeghel, G.; Jacquemier, J.; Castellano, R.; Goncalves, A.; Andre, P.; Romagne, F.; Thibault, G.; et al. Human breast cancer cells enhance self tolerance by promoting evasion from NK cell antitumor immunity. J. Clin. Invest. 2011, 121, 3609-3622. [CrossRef]

131. Sheu, B.C.; Chiou, S.H.; Lin, H.H.; Chow, S.N.; Huang, S.C.; Ho, H.N.; Hsu, S.M. Up-regulation of inhibitory natural killer receptors CD94/NKG2A with suppressed intracellular perforin expression of tumor-infiltrating CD8+ T lymphocytes in human cervical carcinoma. Cancer Res. 2005, 65, 2921-2929. [CrossRef] [PubMed]

132. Andre, P.; Denis, C.; Soulas, C.; Bourbon-Caillet, C.; Lopez, J.; Arnoux, T.; Blery, M.; Bonnafous, C.; Gauthier, L.; Morel, A.; et al. Anti-NKG2A mAb Is a Checkpoint Inhibitor that Promotes Anti-tumor Immunity by Unleashing Both T and NK Cells. Cell 2018, 175, 1731-1743. [CrossRef] [PubMed]

133. Moretta, A.; Vitale, M.; Sivori, S.; Bottino, C.; Morelli, L.; Augugliaro, R.; Barbaresi, M.; Pende, D.; Ciccone, E.; Lopez-Botet, M.; et al. Human natural killer cell receptors for HLA-class I molecules. Evidence that the Kp43 (CD94) molecule functions as receptor for HLA-B alleles. J. Exp. Med. 1994, 180, 545-555. [CrossRef] [PubMed]

134. Ruggeri, L.; Urbani, E.; Andre, P.; Mancusi, A.; Tosti, A.; Topini, F.; Blery, M.; Animobono, L.; Romagne, F.; Wagtmann, N.; et al. Effects of anti-NKG2A antibody administration on leukemia and normal hematopoietic cells. Haematologica 2016, 101, 626-633. [CrossRef]

135. McWilliams, E.M.; Mele, J.M.; Cheney, C.; Timmerman, E.A.; Fiazuddin, F.; Strattan, E.J.; Mo, X.; Byrd, J.C.; Muthusamy, N.; Awan, F.T. Therapeutic CD94/NKG2A blockade improves natural killer cell dysfunction in chronic lymphocytic leukemia. OncoImmunology 2016, 5, e1226720. [CrossRef]

136. Moretta, L.; Bottino, C.; Pende, D.; Vitale, M.; Mingari, M.C.; Moretta, A. Different checkpoints in human NK-cell activation. Trends Immunol. 2004, 25, 670-676. [CrossRef]

137. van Hall, T.; Andre, P.; Horowitz, A.; Ruan, D.F.; Borst, L.; Zerbib, R.; Narni-Mancinelli, E.; van der Burg, S.H.; Vivier, E. Monalizumab: Inhibiting the novel immune checkpoint NKG2A. J. Immunother. Cancer 2019, 7, 263. [CrossRef]

138. Moretta, A.; Biassoni, R.; Bottino, C.; Pende, D.; Vitale, M.; Poggi, A.; Mingari, M.C.; Moretta, L. Major histocompatibility complex class I-specific receptors on human natural killer and T lymphocytes. Immunol. Rev. 1997, 155, 105-117. [CrossRef]

139. Jamil, K.M.; Khakoo, S.I. KIR/HLA interactions and pathogen immunity. J. Biomed. Biotechnol. 2011, 2011, 298348. [CrossRef]

140. Long, E.O.; Barber, D.F.; Burshtyn, D.N.; Faure, M.; Peterson, M.; Rajagopalan, S.; Renard, V.; Sandusky, M.; Stebbins, C.C.; Wagtmann, N.; et al. Inhibition of natural killer cell activation signals by killer cell immunoglobulin-like receptors (CD158). Immunol. Rev. 2001, 181, 223-233. [CrossRef]

141. Yusa, S.; Campbell, K.S. Src homology region 2-containing protein tyrosine phosphatase-2 (SHP-2) can play a direct role in the inhibitory function of killer cell Ig-like receptors in human NK cells. J. Immunol. 2003, 170, 4539-4547. [CrossRef] [PubMed]

142. Uhrberg, M.; Valiante, N.M.; Shum, B.P.; Shilling, H.G.; Lienert-Weidenbach, K.; Corliss, B.; Tyan, D.; Lanier, L.L.; Parham, P. Human diversity in killer cell inhibitory receptor genes. Immunity 1997, 7, 753-763. [CrossRef]

143. Purdy, A.K.; Campbell, K.S. Natural killer cells and cancer: Regulation by the killer cell Ig-like receptors (KIR). Cancer Biol. Ther. 2009, 8, 2211-2220. [CrossRef]

144. Yawata, M.; Yawata, N.; Draghi, M.; Little, A.M.; Partheniou, F.; Parham, P. Roles for HLA and KIR polymorphisms in natural killer cell repertoire selection and modulation of effector function. J. Exp. Med. 2006, 203, 633-645. [CrossRef] [PubMed]

145. Velardi, A.; Ruggeri, L.; Moretta, L. NK cells: A lesson from mismatched hematopoietic transplantation. Trends Immunol. 2002, 23, 438-444. [CrossRef]

146. Ruggeri, L.; Capanni, M.; Urbani, E.; Perruccio, K.; Shlomchik, W.D.; Tosti, A.; Posati, S.; Rogaia, D.; Frassoni, F.; Aversa, F.; et al. Effectiveness of donor natural killer cell alloreactivity in mismatched hematopoietic transplants. Science 2002, 295, 2097-2100. [CrossRef] [PubMed]

147. Ruggeri, L.; Capanni, M.; Casucci, M.; Volpi, I.; Tosti, A.; Perruccio, K.; Urbani, E.; Negrin, R.S.; Martelli, M.F.; Velardi, A. Role of natural killer cell alloreactivity in HLA-mismatched hematopoietic stem cell transplantation. Blood 1999, 94, 333-339. [CrossRef] 
148. Shi, J.; Tricot, G.; Szmania, S.; Rosen, N.; Garg, T.K.; Malaviarachchi, P.A.; Moreno, A.; Dupont, B.; Hsu, K.C.; Baxter-Lowe, L.A.; et al. Infusion of haplo-identical killer immunoglobulin-like receptor ligand mismatched NK cells for relapsed myeloma in the setting of autologous stem cell transplantation. Br. J. Haematol. 2008, 143, 641-653. [CrossRef]

149. Kohrt, H.E.; Thielens, A.; Marabelle, A.; Sagiv-Barfi, I.; Sola, C.; Chanuc, F.; Fuseri, N.; Bonnafous, C.; Czerwinski, D.; Rajapaksa, A.; et al. Anti-KIR antibody enhancement of anti-lymphoma activity of natural killer cells as monotherapy and in combination with anti-CD20 antibodies. Blood 2014, 123, 678-686. [CrossRef]

150. Benson, D.M., Jr.; Cohen, A.D.; Jagannath, S.; Munshi, N.C.; Spitzer, G.; Hofmeister, C.C.; Efebera, Y.A.; Andre, P.; Zerbib, R.; Caligiuri, M.A. A Phase I Trial of the Anti-KIR Antibody IPH2101 and Lenalidomide in Patients with Relapsed/Refractory Multiple Myeloma. Clin. Cancer Res. 2015, 21, 4055-4061. [CrossRef]

151. Vey, N.; Karlin, L.; Sadot-Lebouvier, S.; Broussais, F.; Berton-Rigaud, D.; Rey, J.; Charbonnier, A.; Marie, D.; Andre, P.; Paturel, C.; et al. A phase 1 study of lirilumab (antibody against killer immunoglobulin-like receptor antibody KIR2D; IPH2102) in patients with solid tumors and hematologic malignancies. Oncotarget 2018, 9, 17675-17688. [CrossRef] [PubMed]

152. Bagot, M.; Porcu, P.; Marie-Cardine, A.; Battistella, M.; William, B.M.; Vermeer, M.; Whittaker, S.; Rotolo, F.; Ram-Wolff, C.; Khodadoust, M.S.; et al. IPH4102, a first-in-class anti-KIR3DL2 monoclonal antibody, in patients with relapsed or refractory cutaneous T-cell lymphoma: An international, first-in-human, open-label, phase 1 trial. Lancet Oncol. 2019, 20, 1160-1170. [CrossRef]

153. Vey, N.; Bourhis, J.H.; Boissel, N.; Bordessoule, D.; Prebet, T.; Charbonnier, A.; Etienne, A.; Andre, P.; Romagne, F.; Benson, D.; et al. A phase 1 trial of the anti-inhibitory KIR mAb IPH2101 for AML in complete remission. Blood 2012, 120, 4317-4323. [CrossRef]

154. Perez-Santos, M.; Guerrero-Gonzalez, T.; Gomez-Conde, E.; Cebada, J.; Flores, A.; Villa-Ruano, N. Treatment of cancer with an anti-KIR antibody: A patent evaluation of US9879082 and US2018208652. Expert. Opin. Ther. Pat. 2020, 30, 159-162. [CrossRef]

155. Anderson, A.C.; Joller, N.; Kuchroo, V.K. Lag-3, Tim-3, and TIGIT: Co-inhibitory Receptors with Specialized Functions in Immune Regulation. Immunity 2016, 44, 989-1004. [CrossRef]

156. Deuss, F.A.; Watson, G.M.; Fu, Z.; Rossjohn, J.; Berry, R. Structural Basis for CD96 Immune Receptor Recognition of Nectin-like Protein-5, CD155. Structure 2019, 27, 219-228. [CrossRef]

157. Dougall, W.C.; Kurtulus, S.; Smyth, M.J.; Anderson, A.C. TIGIT and CD96: New checkpoint receptor targets for cancer immunotherapy. Immunol. Rev. 2017, 276, 112-120. [CrossRef] [PubMed]

158. Chan, C.J.; Martinet, L.; Gilfillan, S.; Souza-Fonseca-Guimaraes, F.; Chow, M.T.; Town, L.; Ritchie, D.S.; Colonna, M.; Andrews, D.M.; Smyth, M.J. The receptors CD96 and CD226 oppose each other in the regulation of natural killer cell functions. Nat. Immunol. 2014, 15, 431-438. [CrossRef] [PubMed]

159. Bowers, J.R.; Readler, J.M.; Sharma, P.; Excoffon, K. Poliovirus Receptor: More than a simple viral receptor. Virus Res. 2017, 242, 1-6. [CrossRef]

160. Kucan Brlic, P.; Lenac Rovis, T.; Cinamon, G.; Tsukerman, P.; Mandelboim, O.; Jonjic, S. Targeting PVR (CD155) and its receptors in anti-tumor therapy. Cell. Mol. Immunol. 2019, 16, 40-52. [CrossRef]

161. Liu, S.; Zhang, H.; Li, M.; Hu, D.; Li, C.; Ge, B.; Jin, B.; Fan, Z. Recruitment of Grb2 and SHIP1 by the ITT-like motif of TIGIT suppresses granule polarization and cytotoxicity of NK cells. Cell Death Differ. 2013, 20, 456-464. [CrossRef] [PubMed]

162. Li, M.; Xia, P.; Du, Y.; Liu, S.; Huang, G.; Chen, J.; Zhang, H.; Hou, N.; Cheng, X.; Zhou, L.; et al. T-cell immunoglobulin and ITIM domain (TIGIT) receptor/poliovirus receptor (PVR) ligand engagement suppresses interferon-gamma production of natural killer cells via beta-arrestin 2-mediated negative signaling. J. Biol. Chem. 2014, 289, 17647-17657. [CrossRef] [PubMed]

163. Solomon, B.L.; Garrido-Laguna, I. TIGIT: A novel immunotherapy target moving from bench to bedside. Cancer Immunol. Immunother. 2018, 67, 1659-1667. [CrossRef]

164. Stanietsky, N.; Simic, H.; Arapovic, J.; Toporik, A.; Levy, O.; Novik, A.; Levine, Z.; Beiman, M.; Dassa, L.; Achdout, H.; et al. The interaction of TIGIT with PVR and PVRL2 inhibits human NK cell cytotoxicity. Proc. Natl. Acad. Sci. USA 2009, 106, 17858-17863. [CrossRef] 
165. Hattori, N.; Kawaguchi, Y.; Sasaki, Y.; Shimada, S.; Murai, S.; Abe, M.; Baba, Y.; Watanuki, M.; Fujiwara, S.; Arai, N.; et al. Monitoring TIGIT/DNAM-1 and PVR/PVRL2 Immune Checkpoint Expression Levels in Allogeneic Stem Cell Transplantation for Acute Myeloid Leukemia. Biol. Blood Marrow. Transpl. 2019, 25, 861-867. [CrossRef]

166. Kurtulus, S.; Sakuishi, K.; Ngiow, S.F.; Joller, N.; Tan, D.J.; Teng, M.W.; Smyth, M.J.; Kuchroo, V.K.; Anderson, A.C. TIGIT predominantly regulates the immune response via regulatory T cells. J. Clin. Invest. 2015, 125, 4053-4062. [CrossRef]

167. Blake, S.J.; Dougall, W.C.; Miles, J.J.; Teng, M.W.; Smyth, M.J. Molecular Pathways: Targeting CD96 and TIGIT for Cancer Immunotherapy. Clin. Cancer Res. 2016, 22, 5183-5188. [CrossRef] [PubMed]

168. Perez-Santos, M.; Anaya-Ruiz, M.; Herrera-Camacho, I.; Rosas-Murrieta, N.H.; Millan-Perez Pena, L. Cancer combinatorial immunotherapy using etigilimab and nivolumab: A patent evaluation of WO2018102536. Expert Opin. Ther. Pat. 2020, 30, 83-86. [CrossRef]

169. Macauley, M.S.; Crocker, P.R.; Paulson, J.C. Siglec-mediated regulation of immune cell function in disease. Nat. Rev. Immunol. 2014, 14, 653-666. [CrossRef] [PubMed]

170. Nicoll, G.; Ni, J.; Liu, D.; Klenerman, P.; Munday, J.; Dubock, S.; Mattei, M.G.; Crocker, P.R. Identification and characterization of a novel siglec, siglec-7, expressed by human natural killer cells and monocytes. J. Biol. Chem. 1999, 274, 34089-34095. [CrossRef]

171. Jandus, C.; Boligan, K.F.; Chijioke, O.; Liu, H.; Dahlhaus, M.; Demoulins, T.; Schneider, C.; Wehrli, M.; Hunger, R.E.; Baerlocher, G.M.; et al. Interactions between Siglec-7/9 receptors and ligands influence NK cell-dependent tumor immunosurveillance. J. Clin. Invest. 2014, 124, 1810-1820. [CrossRef] [PubMed]

172. Von Gunten, S.; Simon, H.U. Natural anti-Siglec autoantibodies mediate potential immunoregulatory mechanisms: Implications for the clinical use of intravenous immunoglobulins (IVIg). Autoimmun. Rev. 2008, 7, 453-456. [CrossRef] [PubMed]

173. Bull, C.; den Brok, M.H.; Adema, G.J. Sweet escape: Sialic acids in tumor immune evasion. Biochim. Biophys. Acta 2014, 1846, 238-246. [CrossRef]

174. Fuster, M.M.; Esko, J.D. The sweet and sour of cancer: Glycans as novel therapeutic targets. Nat. Rev. Cancer 2005, 5, 526-542. [CrossRef]

175. Hudak, J.E.; Canham, S.M.; Bertozzi, C.R. Glycocalyx engineering reveals a Siglec-based mechanism for NK cell immunoevasion. Nat. Chem. Biol. 2014, 10, 69-75. [CrossRef]

176. Xiao, H.; Woods, E.C.; Vukojicic, P.; Bertozzi, C.R. Precision glycocalyx editing as a strategy for cancer immunotherapy. Proc. Natl. Acad. Sci. USA 2016, 113, 10304-10309. [CrossRef]

177. Triebel, F.; Jitsukawa, S.; Baixeras, E.; Roman-Roman, S.; Genevee, C.; Viegas-Pequignot, E.; Hercend, T. LAG-3, a novel lymphocyte activation gene closely related to CD4. J. Exp. Med. 1990, 171, 1393-1405. [CrossRef]

178. Workman, C.J.; Dugger, K.J.; Vignali, D.A. Cutting edge: Molecular analysis of the negative regulatory function of lymphocyte activation gene-3. J. Immunol. 2002, 169, 5392-5395. [CrossRef] [PubMed]

179. Demeure, C.E.; Wolfers, J.; Martin-Garcia, N.; Gaulard, P.; Triebel, F. T Lymphocytes infiltrating various tumour types express the MHC class II ligand lymphocyte activation gene-3 (LAG-3): Role of LAG-3/MHC class II interactions in cell-cell contacts. Eur. J. Cancer 2001, 37, 1709-1718. [CrossRef]

180. Huang, C.T.; Workman, C.J.; Flies, D.; Pan, X.; Marson, A.L.; Zhou, G.; Hipkiss, E.L.; Ravi, S.; Kowalski, J.; Levitsky, H.I.; et al. Role of LAG-3 in regulatory T cells. Immunity 2004, 21, 503-513. [CrossRef]

181. Kisielow, M.; Kisielow, J.; Capoferri-Sollami, G.; Karjalainen, K. Expression of lymphocyte activation gene 3 (LAG-3) on B cells is induced by T cells. Eur. J. Immunol. 2005, 35, 2081-2088. [CrossRef] [PubMed]

182. Andreae, S.; Buisson, S.; Triebel, F. MHC class II signal transduction in human dendritic cells induced by a natural ligand, the LAG-3 protein (CD223). Blood 2003, 102, 2130-2137. [CrossRef] [PubMed]

183. Liu, W.; Tang, L.; Zhang, G.; Wei, H.; Cui, Y.; Guo, L.; Gou, Z.; Chen, X.; Jiang, D.; Zhu, Y.; et al. Characterization of a novel C-type lectin-like gene, LSECtin: Demonstration of carbohydrate binding and expression in sinusoidal endothelial cells of liver and lymph node. J. Biol. Chem. 2004, 279, 18748-18758. [CrossRef]

184. Workman, C.J.; Vignali, D.A. Negative regulation of T cell homeostasis by lymphocyte activation gene-3 (CD223). J. Immunol. 2005, 174, 688-695. [CrossRef]

185. Macon-Lemaitre, L.; Triebel, F. The negative regulatory function of the lymphocyte-activation gene-3 co-receptor (CD223) on human T cells. Immunology 2005, 115, 170-178. [CrossRef] 
186. Blackburn, S.D.; Shin, H.; Haining, W.N.; Zou, T.; Workman, C.J.; Polley, A.; Betts, M.R.; Freeman, G.J.; Vignali, D.A.; Wherry, E.J. Coregulation of CD8+ T cell exhaustion by multiple inhibitory receptors during chronic viral infection. Nat. Immunol. 2009, 10, 29-37. [CrossRef]

187. Wherry, E.J.; Kurachi, M. Molecular and cellular insights into T cell exhaustion. Nat. Rev. Immunol. 2015, 15, 486-499. [CrossRef]

188. Miyazaki, T.; Dierich, A.; Benoist, C.; Mathis, D. Independent modes of natural killing distinguished in mice lacking Lag3. Science 1996, 272, 405-408. [CrossRef]

189. Huard, B.; Tournier, M.; Triebel, F. LAG-3 does not define a specific mode of natural killing in human. Immunol. Lett. 1998, 61, 109-112. [CrossRef]

190. Brignone, C.; Grygar, C.; Marcu, M.; Schakel, K.; Triebel, F. A soluble form of lymphocyte activation gene-3 (IMP321) induces activation of a large range of human effector cytotoxic cells. J. Immunol. 2007, 17, 4202-4211. [CrossRef]

191. He, Y.; Rivard, C.J.; Rozeboom, L.; Yu, H.; Ellison, K.; Kowalewski, A.; Zhou, C.; Hirsch, F.R. Lymphocyte-activation gene-3, an important immune checkpoint in cancer. Cancer Sci. 2016, 107, 1193-1197. [CrossRef] [PubMed]

192. Woo, S.R.; Turnis, M.E.; Goldberg, M.V.; Bankoti, J.; Selby, M.; Nirschl, C.J.; Bettini, M.L.; Gravano, D.M.; Vogel, P.; Liu, C.L.; et al. Immune inhibitory molecules LAG-3 and PD-1 synergistically regulate T-cell function to promote tumoral immune escape. Cancer Res. 2012, 72, 917-927. [CrossRef] [PubMed]

193. Friedlaender, A.; Addeo, A.; Banna, G. New emerging targets in cancer immunotherapy: The role of TIM3. Esmo Open 2019, 4 (Suppl. S3), e000497. [CrossRef]

194. Gautron, A.S.; Dominguez-Villar, M.; de Marcken, M.; Hafler, D.A. Enhanced suppressor function of TIM-3+ FoxP3+ regulatory T cells. Eur. J. Immunol. 2014, 44, 2703-2711. [CrossRef] [PubMed]

195. Avery, L.; Filderman, J.; Szymczak-Workman, A.L.; Kane, L.P. Tim-3 co-stimulation promotes short-lived effector T cells, restricts memory precursors, and is dispensable for T cell exhaustion. Proc. Natl. Acad. Sci. USA 2018, 115, 2455-2460. [CrossRef] [PubMed]

196. Gleason, M.K.; Lenvik, T.R.; McCullar, V.; Felices, M.; O’Brien, M.S.; Cooley, S.A.; Verneris, M.R.; Cichocki, F.; Holman, C.J.; Panoskaltsis-Mortari, A.; et al. Tim-3 is an inducible human natural killer cell receptor that enhances interferon gamma production in response to galectin-9. Blood 2012, 119, 3064-3072. [CrossRef]

197. So, E.C.; Khaladj-Ghom, A.; Ji, Y.; Amin, J.; Song, Y.; Burch, E.; Zhou, H.; Sun, H.; Chen, S.; Bentzen, S.; et al. NK cell expression of Tim-3: First impressions matter. Immunobiology 2019, 224, 362-370. [CrossRef]

198. Ndhlovu, L.C.; Lopez-Verges, S.; Barbour, J.D.; Jones, R.B.; Jha, A.R.; Long, B.R.; Schoeffler, E.C.; Fujita, T.; Nixon, D.F.; Lanier, L.L. Tim-3 marks human natural killer cell maturation and suppresses cell-mediated cytotoxicity. Blood 2012, 119, 3734-3743. [CrossRef]

199. Wang, Z.; Zhu, J.; Gu, H.; Yuan, Y.; Zhang, B.; Zhu, D.; Zhou, J.; Zhu, Y.; Chen, W. The Clinical Significance of Abnormal Tim-3 Expression on NK Cells from Patients with Gastric Cancer. Immunol. Invest. 2015, 44, 578-589. [CrossRef]

200. Xu, L.; Huang, Y.; Tan, L.; Yu, W.; Chen, D.; Lu, C.; He, J.; Wu, G.; Liu, X.; Zhang, Y. Increased Tim-3 expression in peripheral NK cells predicts a poorer prognosis and Tim-3 blockade improves NK cell-mediated cytotoxicity in human lung adenocarcinoma. Int. Immunopharmacol. 2015, 29, 635-641. [CrossRef]

201. Da Silva, I.P.; Gallois, A.; Jimenez-Baranda, S.; Khan, S.; Anderson, A.C.; Kuchroo, V.K.; Osman, I.; Bhardwaj, N. Reversal of NK-cell exhaustion in advanced melanoma by Tim-3 blockade. Cancer Immunol. Res. 2014, 2, 410-422. [CrossRef] [PubMed]

202. Golden-Mason, L.; McMahan, R.H.; Strong, M.; Reisdorph, R.; Mahaffey, S.; Palmer, B.E.; Cheng, L.; Kulesza, C.; Hirashima, M.; Niki, T.; et al. Galectin-9 functionally impairs natural killer cells in humans and mice. J. Virol. 2013, 87, 4835-4845. [CrossRef] [PubMed]

203. Khan, M.; Arooj, S.; Wang, H. NK Cell-Based Immune Checkpoint Inhibition. Front. Immunol. 2020, 11, 167. [CrossRef]

204. Lougaris, V.; Tabellini, G.; Baronio, M.; Patrizi, O.; Gazzurelli, L.; Mitsuiki, N.; Pozzi, M.R.; Grimbacher, B.; Parolini, S.; Plebani, A. CTLA-4 regulates human Natural Killer cell effector functions. Clin. Immunol. 2018, 194, 43-45. [CrossRef]

205. Stojanovic, A.; Fiegler, N.; Brunner-Weinzierl, M.; Cerwenka, A. CTLA-4 is expressed by activated mouse NK cells and inhibits NK Cell IFN-gamma production in response to mature dendritic cells. J. Immunol. 2014, 192, 4184-4191. [CrossRef] [PubMed] 
206. Beldi-Ferchiou, A.; Caillat-Zucman, S. Control of NK Cell Activation by Immune Checkpoint Molecules. Int. J. Mol. Sci. 2017, 18, 2129. [CrossRef] [PubMed]

207. Schubert, D.; Bode, C.; Kenefeck, R.; Hou, T.Z.; Wing, J.B.; Kennedy, A.; Bulashevska, A.; Petersen, B.S.; Schaffer, A.A.; Gruning, B.A.; et al. Autosomal dominant immune dysregulation syndrome in humans with CTLA4 mutations. Nat. Med. 2014, 20, 1410-1416. [CrossRef]

208. Kuehn, H.S.; Ouyang, W.; Lo, B.; Deenick, E.K.; Niemela, J.E.; Avery, D.T.; Schickel, J.N.; Tran, D.Q.; Stoddard, J.; Zhang, Y.; et al. Immune dysregulation in human subjects with heterozygous germline mutations in CTLA4. Science 2014, 345, 1623-1627. [CrossRef]

209. Schwab, C.; Gabrysch, A.; Olbrich, P.; Patino, V.; Warnatz, K.; Wolff, D.; Hoshino, A.; Kobayashi, M.; Imai, K.; Takagi, M.; et al. Phenotype, penetrance, and treatment of 133 cytotoxic T-lymphocyte antigen 4-insufficient subjects. J. Allergy Clin. Immunol. 2018, 142, 1932-1946. [CrossRef]

210. Pentcheva-Hoang, T.; Egen, J.G.; Wojnoonski, K.; Allison, J.P. B7-1 and B7-2 selectively recruit CTLA-4 and CD28 to the immunological synapse. Immunity 2004, 21, 401-413. [CrossRef]

211. Yokosuka, T.; Kobayashi, W.; Takamatsu, M.; Sakata-Sogawa, K.; Zeng, H.; Hashimoto-Tane, A.; Yagita, H.; Tokunaga, M.; Saito, T. Spatiotemporal basis of CTLA-4 costimulatory molecule-mediated negative regulation of T cell activation. Immunity 2010, 33, 326-339. [CrossRef] [PubMed]

212. Rowshanravan, B.; Halliday, N.; Sansom, D.M. CTLA-4: A moving target in immunotherapy. Blood 2018, 131, 58-67. [CrossRef] [PubMed]

213. Tocut, M.; Brenner, R.; Zandman-Goddard, G. Autoimmune phenomena and disease in cancer patients treated with immune checkpoint inhibitors. Autoimmun. Rev. 2018, 17, 610-616. [CrossRef] [PubMed]

214. Anderson, R.; Rapoport, B.L. Immune Dysregulation in Cancer Patients Undergoing Immune Checkpoint Inhibitor Treatment and Potential Predictive Strategies for Future Clinical Practice. Front. Oncol. 2018, 8, 80. [CrossRef]

215. Takahashi, T.; Tagami, T.; Yamazaki, S.; Uede, T.; Shimizu, J.; Sakaguchi, N.; Mak, T.W.; Sakaguchi, S. Immunologic self-tolerance maintained by CD25(+)CD4(+) regulatory $\mathrm{T}$ cells constitutively expressing cytotoxic T lymphocyte-associated antigen 4. J. Exp. Med. 2000, 192, 303-310. [CrossRef]

216. Jie, H.B.; Schuler, P.J.; Lee, S.C.; Srivastava, R.M.; Argiris, A.; Ferrone, S.; Whiteside, T.L.; Ferris, R.L. CTLA-4(+) Regulatory T Cells Increased in Cetuximab-Treated Head and Neck Cancer Patients Suppress NK Cell Cytotoxicity and Correlate with Poor Prognosis. Cancer Res. 2015, 75, 2200-2210. [CrossRef]

217. Romano, E.; Kusio-Kobialka, M.; Foukas, P.G.; Baumgaertner, P.; Meyer, C.; Ballabeni, P.; Michielin, O.; Weide, B.; Romero, P.; Speiser, D.E. Ipilimumab-dependent cell-mediated cytotoxicity of regulatory T cells ex vivo by nonclassical monocytes in melanoma patients. Proc. Natl. Acad. Sci. USA 2015, 112, 6140-6145. [CrossRef]

218. Lotze, M.T.; Matory, Y.L.; Ettinghausen, S.E.; Rayner, A.A.; Sharrow, S.O.; Seipp, C.A.; Custer, M.C.; Rosenberg, S.A. In vivo administration of purified human interleukin 2. II. Half life, immunologic effects, and expansion of peripheral lymphoid cells in vivo with recombinant IL 2. J. Immunol. 1985, 135, 2865-2875.

219. Hannani, D.; Vetizou, M.; Enot, D.; Rusakiewicz, S.; Chaput, N.; Klatzmann, D.; Desbois, M.; Jacquelot, N.; Vimond, N.; Chouaib, S.; et al. Anticancer immunotherapy by CTLA-4 blockade: Obligatory contribution of IL-2 receptors and negative prognostic impact of soluble CD25. Cell Res. 2015, 25, 208-224. [CrossRef]

220. Sanseviero, E.; O’Brien, E.M.; Karras, J.R.; Shabaneh, T.B.; Aksoy, B.A.; Xu, W.; Zheng, C.; Yin, X.; Xu, X.; Karakousis, G.C.; et al. Anti-CTLA-4 Activates Intratumoral NK Cells and Combined with IL15/IL15Ralpha Complexes Enhances Tumor Control. Cancer Immunol. Res. 2019, 7, 1371-1380. [CrossRef]

221. Hodi, F.S.; O’Day, S.J.; McDermott, D.F.; Weber, R.W.; Sosman, J.A.; Haanen, J.B.; Gonzalez, R.; Robert, C.; Schadendorf, D.; Hassel, J.C.; et al. Improved survival with ipilimumab in patients with metastatic melanoma. N. Engl. J. Med. 2010, 363, 711-723. [CrossRef] [PubMed]

222. Rotte, A. Combination of CTLA-4 and PD-1 blockers for treatment of cancer. J. Exp. Clin. Cancer Res. 2019, 38, 255. [CrossRef]

223. Kirkwood, J.M.; Lorigan, P.; Hersey, P.; Hauschild, A.; Robert, C.; McDermott, D.; Marshall, M.A.; Gomez-Navarro, J.; Liang, J.Q.; Bulanhagui, C.A. Phase II trial of tremelimumab $(\mathrm{CP}-675,206)$ in patients with advanced refractory or relapsed melanoma. Clin. Cancer Res. 2010, 16, 1042-1048. [CrossRef]

224. Ribas, A.; Kefford, R.; Marshall, M.A.; Punt, C.J.; Haanen, J.B.; Marmol, M.; Garbe, C.; Gogas, H.; Schachter, J.; Linette, G.; et al. Phase III randomized clinical trial comparing tremelimumab with standard-of-care chemotherapy in patients with advanced melanoma. J. Clin. Oncol. 2013, 31, 616-622. [CrossRef] [PubMed] 
225. Buchbinder, E.I.; Desai, A. CTLA-4 and PD-1 Pathways: Similarities, Differences, and Implications of Their Inhibition. Am. J. Clin. Oncol. 2016, 39, 98-106. [CrossRef] [PubMed]

226. Fife, B.T.; Bluestone, J.A. Control of peripheral T-cell tolerance and autoimmunity via the CTLA-4 and PD-1 pathways. Immunol. Rev. 2008, 224, 166-182. [CrossRef] [PubMed]

227. Mariotti, F.R.; Petrini, S.; Ingegnere, T.; Tumino, N.; Besi, F.; Scordamaglia, F.; Munari, E.; Pesce, S.; Marcenaro, E.; Moretta, A.; et al. PD-1 in human NK cells: Evidence of cytoplasmic mRNA and protein expression. OncoImmunology 2019, 8, 1557030. [CrossRef]

228. Liu, Y.; Cheng, Y.; Xu, Y.; Wang, Z.; Du, X.; Li, C.; Peng, J.; Gao, L.; Liang, X.; Ma, C. Increased expression of programmed cell death protein 1 on NK cells inhibits NK-cell-mediated anti-tumor function and indicates poor prognosis in digestive cancers. Oncogene 2017, 36, 6143-6153. [CrossRef]

229. Della Chiesa, M.; Pesce, S.; Muccio, L.; Carlomagno, S.; Sivori, S.; Moretta, A.; Marcenaro, E. Features of Memory-Like and PD-1(+) Human NK Cell Subsets. Front. Immunol. 2016, 7, 351. [CrossRef]

230. Hicks, K.C.; Fantini, M.; Donahue, R.N.; Schwab, A.; Knudson, K.M.; Tritsch, S.R.; Jochems, C.; Clavijo, P.E.; Allen, C.T.; Hodge, J.W.; et al. Epigenetic priming of both tumor and NK cells augments antibody-dependent cellular cytotoxicity elicited by the anti-PD-L1 antibody avelumab against multiple carcinoma cell types. OncoImmunology 2018, 7, e1466018. [CrossRef]

231. Julia, E.P.; Amante, A.; Pampena, M.B.; Mordoh, J.; Levy, E.M. Avelumab, an IgG1 anti-PD-L1 Immune Checkpoint Inhibitor, Triggers NK Cell-Mediated Cytotoxicity and Cytokine Production Against Triple Negative Breast Cancer Cells. Front. Immunol. 2018, 9, 2140. [CrossRef] [PubMed]

232. Berger, R.; Rotem-Yehudar, R.; Slama, G.; Landes, S.; Kneller, A.; Leiba, M.; Koren-Michowitz, M.; Shimoni, A.; Nagler, A. Phase I safety and pharmacokinetic study of CT-011, a humanized antibody interacting with PD-1, in patients with advanced hematologic malignancies. Clin. Cancer Res. 2008, 14, 3044-3051. [CrossRef] [PubMed]

233. Infante, J.R.; Powderly, J.D.; Burris, H.A.; Kittaneh, M.; Grice, J.H.; Smothers, J.F.; Brett, S.; Fleming, M.E.; May, R.; Marshall, S.; et al. Clinical and pharmacodynamic (PD) results of a phase I trial with AMP-224 (B7-DC Fc) that binds to the PD-1 receptor. J. Clin. Oncol. 2013, 31 (Suppl. S15), 3044. [CrossRef]

234. Sadelain, M.; Brentjens, R.; Riviere, I. The basic principles of chimeric antigen receptor design. Cancer Discov. 2013, 3, 388-398. [CrossRef] [PubMed]

235. Eshhar, Z.; Waks, T.; Gross, G.; Schindler, D.G. Specific activation and targeting of cytotoxic lymphocytes through chimeric single chains consisting of antibody-binding domains and the gamma or zeta subunits of the immunoglobulin and T-cell receptors. Proc. Natl. Acad. Sci. USA 1993, 90, 720-724. [CrossRef] [PubMed]

236. Sadelain, M. Chimeric antigen receptors: Driving immunology towards synthetic biology. Curr. Opin. Immunol. 2016, 41, 68-76. [CrossRef] [PubMed]

237. Qu, C.; Ping, N.; Kang, L.; Liu, H.; Qin, S.; Wu, Q.; Chen, X.; Zhou, M.; Xia, F.; Ye, A.; et al. Radiation Priming Chimeric Antigen Receptor T-Cell Therapy in Relapsed/Refractory Diffuse Large B-Cell Lymphoma With High Tumor Burden. J. Immunother. 2020, 43, 32-37. [CrossRef] [PubMed]

238. Graham, C.; Hewitson, R.; Pagliuca, A.; Benjamin, R. Cancer immunotherapy with CAR-T cells-behold the future. Clin. Med. 2018, 18, 324-328. [CrossRef]

239. Daher, M.; Rezvani, K. Next generation natural killer cells for cancer immunotherapy: The promise of genetic engineering. Curr. Opin. Immunol. 2018, 51, 146-153. [CrossRef]

240. Lang, S.; Vujanovic, N.L.; Wollenberg, B.; Whiteside, T.L. Absence of B7.1-CD28/CTLA-4-mediated co-stimulation in human NK cells. Eur. J. Immunol. 1998, 28, 780-786. [CrossRef]

241. Pule, M.A.; Straathof, K.C.; Dotti, G.; Heslop, H.E.; Rooney, C.M.; Brenner, M.K. A chimeric T cell antigen receptor that augments cytokine release and supports clonal expansion of primary human T cells. Mol. Ther. 2005, 12, 933-941. [CrossRef] [PubMed]

(C) 2020 by the authors. Licensee MDPI, Basel, Switzerland. This article is an open access article distributed under the terms and conditions of the Creative Commons Attribution (CC BY) license (http://creativecommons.org/licenses/by/4.0/). 